\title{
Short-term clinical outcomes among patients undergoing transcatheter aortic valve implantation in Switzerland: the Swiss TAVI registry
}

Peter Wenaweser ${ }^{1 *}$, MD; Stefan Stortecky¹, MD; Dik Heg², PhD; David Tueller ${ }^{3}, \mathrm{MD}$; Fabian Nietlispach ${ }^{4}, \mathrm{MD}^{2}$ Volkmar Falk4, MD; Giovanni Pedrazzini', MD; Raban Jeger ${ }^{6}$, MD; Oliver Reuthebuch ${ }^{6}$, MD; Thierry Carrel $^{1}$, MD; Lorenz Räber ${ }^{1}$, MD; Franz W. Amann ${ }^{7}$, MD; Enrico Ferrari ${ }^{8}$, MD; Stefan Toggweiler ${ }^{9}$, MD; Stephane Noble ${ }^{10}$, MD; Marco Roffi ${ }^{10}$, MD; Jürg Gruenenfelder ${ }^{11}$, MD; Peter Jüni², MD; Stephan Windecker ${ }^{1}$, MD; Christoph Huber ${ }^{1}$, MD

\section{Department of Cardiology and Department of Cardiovascular Surgery, Swiss Cardiovascular Centre, Bern University Hospital, Bern, Switzerland; 2. Department of Clinical Research, Clinical Trials Unit, University of Bern, Bern, Switzerland; 3. Triemli Hospital Zurich, Zurich, Switzerland; 4. Department of Cardiology and Department of Cardiovascular Surgery, University Heart Centre Zurich, University Hospital Zurich, Zurich, Switzerland; 5. Department of Cardiology, Cardiocentro Ticino, Lugano, Switzerland; 6. Department of Cardiology and Department of Cardiovascular Surgery, Basel University Hospital, University of Basel, Basel, Switzerland; 7. Department of Cardiology, Klinik im Park, Hirslanden Clinic Zurich, Zurich, Switzerland; 8. Department of Cardiothoracic Surgery, Lausanne University Hospital, Lausanne, Switzerland; 9. Cantonal Hospital Lucerne, Lucerne, Switzerland; 10. Department of Cardiology, Geneva University Hospital, Geneva, Switzerland; 11. Heart Clinic Hirslanden, Hirslanden Clinic Zurich, Zurich, Switzerland}

\section{P. Wenaweser and S. Stortecky contributed equally to this work.}

The accompanying supplementary data are published online at: http://www.pcronline.com/eurointervention/ahead_of_print/201404-06

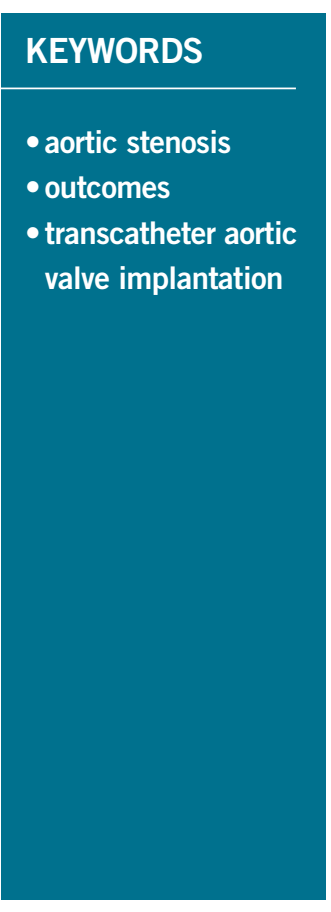

\section{Abstract}

Aims: To evaluate short-term clinical outcomes following transcatheter aortic valve implantation (TAVI) using CE-mark approved devices in Switzerland.

Methods and results: The Swiss TAVI registry is a national, prospective, multicentre, monitored cohort study evaluating clinical outcomes in consecutive patients undergoing TAVI at cardiovascular centres in Switzerland. From February 2011 to March 2013, a total of 697 patients underwent TAVI for native aortic valve stenosis (98.1\%), degenerative aortic bioprosthesis $(1.6 \%)$ or severe aortic regurgitation $(0.3 \%)$. Patients were elderly ( $82.4 \pm 6$ years), $52 \%$ were females, and the majority highly symptomatic ( $73.1 \%$ NYHA III/IV). Patients with severe aortic stenosis (mean gradient $44.8 \pm 17 \mathrm{mmHg}$, aortic valve area $0.7 \pm 0.3 \mathrm{~cm}^{2}$ ) were either deemed inoperable or at high risk for conventional surgery (STS $8.2 \% \pm 7$ ). The transfemoral access was the most frequently used (79.1\%), followed by transapical (18.1\%), direct aortic (1.7\%) and subclavian access $(1.1 \%)$. At 30 days, rates of all-cause mortality, cerebrovascular events and myocardial infarction were $4.8 \%, 3.3 \%$ and $0.4 \%$, respectively. The most frequently observed adverse events were access-related complications (11.8\%), permanent pacemaker implantation (20.5\%) and bleeding complications (16.6\%). The Swiss TAVI registry is registered at ClinicalTrials.gov (NCT01368250).

Conclusions: The Swiss TAVI registry is a national cohort study evaluating consecutive TAVI procedures in Switzerland. This first outcome report provides favourable short-term clinical outcomes in unselected TAVI patients.

\footnotetext{
*Corresponding author: Department of Cardiology, Bern University Hospital, 3010 Bern, Switzerland. E-mail:peterwenaweser@insel.ch
} 


\section{Introduction}

Aortic valve stenosis is the most clinically relevant valvular heart disease in the elderly patient population and is associated with worse clinical outcomes once symptoms occur' ${ }^{1}$. Surgical aortic valve replacement (SAVR) was for decades the standard treatment for patients with symptomatic, severe aortic stenosis, and resulted in effective alleviation of symptoms, improvement of health-related quality of life and overall prognosis ${ }^{2}$. Following the introduction of transcatheter aortic valve implantation (TAVI) in 2002 as a less invasive treatment for symptomatic severe aortic stenosis ${ }^{3}$, TAVI has evolved into a reliable therapeutic alternative with comparable results to SAVR in well-defined patient subgroups ${ }^{4-6}$. Currently, the indication for TAVI is limited to carefully selected patients deemed inoperable or at excessive risk for SAVR ${ }^{2}$. A successful TAVI procedure is preceded by a complex selection process of patients, requiring detailed imaging information of the aortic valve anatomy and the peripheral vasculature, and also a meticulous clinical assessment by an interdisciplinary Heart Team ${ }^{7,8}$.

In the era of the Heart Team, the Swiss Working Group of Interventional Cardiology in collaboration with the Swiss Society of Cardiac Surgery started a nationwide, prospective cohort study in 2011, with the intention of assessing the safety and efficacy of unselected and consecutive TAVI procedures in Switzerland. As the first TAVI in Switzerland was performed in August 2007, this registry mainly focuses on contemporary results of experienced cardiovascular centres in consecutive patients treated with TAVI in Switzerland.

\section{Methods}

The Swiss TAVI registry is a national, prospective cohort study aiming for consecutive patient enrolment, data monitoring and endpoint adjudication by a dedicated clinical events committee according to the recommendations of the Valve Academic Research Consortium (VARC) ${ }^{9,10}$. The Swiss TAVI registry was designed to provide short-term clinical outcomes and long-term clinical data of TAVI patients treated with CE-approved devices.

The aim of the present report was to describe the clinical and procedural characteristics of patients treated with TAVI in Switzerland using different CE-approved devices and various access routes as well as to stratify short-term outcomes according to device type and access route. The study protocol was approved by the local cantonal ethics committee at each participating centre and all patients provided written informed consent. The Swiss TAVI registry is performed under the lead of the Swiss Cardiovascular Centre Bern at Bern University Hospital in cooperation with the Clinical Trials Unit Bern responsible for data management and independent statistical analysis.

\section{Patient population}

A total of 697 patients were enrolled into the Swiss TAVI registry between February 2011 and March 2013, and eight centres participated during this first period of inclusion. Consecutive patient enrolment was mandatory. All participating centres are listed in the Online Appendix.
Patients were eligible for inclusion in case of symptomatic, severe aortic stenosis, degenerated aortic bioprosthesis or severe aortic regurgitation treated with CE-approved TAVI devices. Patient screening and selection was recommended to be performed within a multidisciplinary Heart Team using detailed clinical and anatomical imaging information. The exclusion criterion for participation in the cohort study was the absence of cardiac surgery on-site.

\section{Procedure and devices}

Transcatheter aortic valve procedures were performed using CE-approved devices only. During the inclusion period, the following CE-approved devices were available in Switzerland and used for patient treatment: Medtronic CoreValve ${ }^{\circledR}$ (Medtronic Inc., Minneapolis, MN, USA), Edwards SAPIEN XT (Edwards Lifesciences, Irvine, CA, USA), Symetis Acurate TA ${ }^{\mathrm{TM}}$ (Symetis, Lausanne, Switzerland), JenaValve (JenaValve Technology GmbH, Munich, Germany) and the Portico $^{\text {TM }}$ THV (St. Jude Medical, Minneapolis, MN, USA). There was no pre-specified recommendation regarding access route selection, and the decision as to general anaesthesia or conscious sedation was left to the discretion of the Heart Team and according to local expertise. In addition, there was no specific recommendation for the type and duration of antiplatelet or antithrombotic medication, which was left to the discretion of the operator and according to local expertise.

\section{Definitions and endpoints}

The primary study endpoint with respect to procedural safety was all-cause mortality at 30 days of follow-up. Secondary outcome measures included cardiovascular mortality, cerebrovascular events, myocardial infarction, bleeding complications, vascular or access-related complications and acute kidney injury. Serious adverse events were site reported and checked for plausibility. All events were adjudicated by a clinical events committee, consisting of interventional cardiologists and cardiac surgeons according to the standardised endpoint definitions proposed by the Valve Academic Research Consortium (VARC) ${ }^{9}$.

\section{Data collection and quality control}

Data were collected using standardised case-report forms available on a web-based database (www.swisstaviregistry.ch). The database was maintained by the Clinical Trials Unit at the University of Bern. Apart from baseline, procedural and in-hospital characteristics, the Swiss TAVI registry prospectively collects follow-up data at 30 days, 12 months and also after three and five years following the procedure. Follow-up was performed individually by each centre on the basis of phone calls or clinical visits. Central monitoring by an independent monitor and statistician was performed to verify completeness and accuracy of data entry at each site. Monitoring included all patients; however, no on-site monitoring or patient data validation was performed.

\section{Statistical analysis}

Continuous data are reported as mean \pm standard deviation (SD), and categorical variables are reported as number of patients (\% of 
patients) where appropriate. In-hospital events are reported as counts of first occurrence per (sub-) type of event ( $\%$ of all patients). Thirty-day event rates are reported using time-to-first-event data, graphically presented using Kaplan-Meier curves, with incidence rates calculated from life tables. Event rates at 30 days were compared for patients treated with transvascular vs. surgical access, and also within transfemoral patients comparing the two main devices Medtronic CoreValve and Edwards SAPIEN XT bioprosthesis, using Cox's regressions. Reported are crude hazard ratios (HR; with $95 \%$ confidence intervals) with p-value from Wald chi-square test, or continuity corrected risk ratios (RR; 95\% CI) with p-value from Fisher's exact test in case of zero events. Reported are adjusted HR (95\% CI), where groups are compared including adjustment for age, gender, previous cardiac surgery, peripheral vascular disease, and coronary artery disease. Two-sided p-values $<0.05$ were considered statistically significant. All analyses were performed with Stata version 12 (StataCorp, College Station, TX, USA).

\section{Results}

\section{PATIENT POPULATION}

A total of 697 patients underwent TAVI between February 2011 and March 2013 for native aortic valve stenosis (98.1\%), degenerative aortic bioprosthesis $(1.6 \%)$ and native aortic regurgitation $(0.3 \%)$ and were entered in the Swiss TAVI registry. Elective treatment was performed in $94.9 \%$ of cases, while $5.1 \%$ of patients underwent urgent or emergent intervention due to haemodynamic instability. A multidisciplinary decision for TAVI was reached in $97.0 \%$ of procedures. Mean age was $82.4 \pm 6.2$ years and $51.5 \%$ were female. Patients were highly symptomatic, with $73.1 \%$ presenting in NYHA functional Class III and IV. The mean aortic valve area was $0.74 \pm 0.3 \mathrm{~cm}^{2}$ and the transvalvular mean gradient was $44.8 \pm 17.4 \mathrm{mmHg}$. Patients were considered to be at high surgical risk or inoperable with an estimated risk of mortality at 30 days of $20.2 \pm 12.7 \%$ according to the logistic EuroSCORE and $8.2 \pm 7.1 \%$ according to the STS score. Detailed information on baseline clinical characteristics are summarised in Table 1.

\section{PROCEDURAL CHARACTERISTICS AND RESULTS}

Procedural characteristics and results are presented in Table 2. Most TAVI procedures were performed in the catheterisation laboratory $(74.6 \%)$, the hybrid room $(24.2 \%)$, and the operating room $(1.1 \%)$ using either general anaesthesia $(54.6 \%)$ or conscious sedation (45.4\%). Transfemoral implantation was performed in $79.1 \%$, transapical in $18.1 \%$, the direct aortic access was used in $1.7 \%$ and the subclavian approach in $1.1 \%$, respectively. The majority of patients received balloon aortic valvuloplasty prior to valve insertion (86.7\%). The Medtronic CoreValve was implanted in $48.4 \%$, the Edwards SAPIEN XT in 45.7\%, JenaValve in 3.3\%, the Symetis Acurate TA in $2.4 \%$, and the Portico THV prosthesis in $0.1 \%$ of patients. Most patients received only one prosthesis (95.5\%); however, more than one prosthesis was required in $4.5 \%$ of patients during the intervention. A total of three patients $(0.4 \%)$ did not receive any TAVI prosthesis: one patient was treated with balloon aortic
Table 1. Baseline characteristics.

\begin{tabular}{|c|c|c|}
\hline & $\begin{array}{c}\text { All patients } \\
\quad \mathrm{N}=697\end{array}$ \\
\hline \multicolumn{2}{|l|}{ Age (years) } & $82.4 \pm 6.2$ \\
\hline \multicolumn{2}{|c|}{ Female gender, n (\%) } & $359(51.5)$ \\
\hline \multicolumn{2}{|c|}{ Body mass index $\left(\mathrm{kg} / \mathrm{m}^{2}\right)$} & $26.3 \pm 5.0$ \\
\hline \multirow{3}{*}{$\begin{array}{l}\text { Cardiac risk } \\
\text { factors }\end{array}$} & Diabetes mellitus, n (\%) & $204(29.3)$ \\
\hline & Dyslipidaemia, n (\%) & $387(55.5)$ \\
\hline & Hypertension, n (\%) & $574(82.4)$ \\
\hline \multirow{4}{*}{$\begin{array}{l}\text { Past } \\
\text { medical } \\
\text { history }\end{array}$} & Previous pacemaker implantation, $\mathrm{n}(\%)$ & $69(9.9)$ \\
\hline & Previous myocardial infarction, $\mathrm{n}(\%)$ & $105(15.1)$ \\
\hline & Previous cardiac surgery, $\mathrm{n}(\%)$ & $104(14.9)$ \\
\hline & Previous stroke, $\mathrm{n}(\%)$ & $83(11.9)$ \\
\hline \multirow{6}{*}{$\begin{array}{l}\text { Clinical } \\
\text { features }\end{array}$} & Peripheral vascular disease, $\mathrm{n}(\%)$ & $137(19.7)$ \\
\hline & $\begin{array}{l}\text { Chronic obstructive pulmonary disease, } \\
\mathrm{n}(\%)\end{array}$ & 109 (15.6) \\
\hline & Coronary artery disease, $\mathrm{n}(\%)$ & $390(56.0)$ \\
\hline & Left ventricular ejection fraction (\%) & $53.8 \pm 14.1$ \\
\hline & Aortic valve area $\left(\mathrm{cm}^{2}\right)$ & $0.74 \pm 0.3$ \\
\hline & Mean transaortic gradient $(\mathrm{mmHg})$ & $44.8 \pm 17.4$ \\
\hline \multirow{7}{*}{$\begin{array}{l}\text { Symptoms } \\
\text { on } \\
\text { admission }\end{array}$} & \multicolumn{2}{|c|}{ New York Heart Association (NYHA) functional class } \\
\hline & NYHA I or II, n (\%) & $186(26.9)$ \\
\hline & NYHA III or IV, n (\%) & $505(73.1)$ \\
\hline & \multicolumn{2}{|c|}{ Canadian Cardiovascular Society (CCS) angina class } \\
\hline & No angina, $\mathrm{n}(\%)$ & $496(71.2)$ \\
\hline & CCS I or II, n (\%) & $114(16.4)$ \\
\hline & CCS III or IV, n (\%) & $87(12.5)$ \\
\hline \multirow{2}{*}{$\begin{array}{l}\text { Risk } \\
\text { assessment }\end{array}$} & Log. EuroSCORE (\%) & $20.2 \pm 12.7$ \\
\hline & STS score (\%) & $8.2 \pm 7.1$ \\
\hline
\end{tabular}

valvuloplasty only, one patient was converted to surgical aortic valve replacement due to heavy calcification of the native aortic valve, and one patient died following balloon aortic valvuloplasty and prior to any valve insertion. Conversion to surgery occurred in $0.9 \%$ of patients.

Information on the in-hospital course after TAVI is provided in Table 3. Cumulative mean duration of hospital length of stay was $10.7 \pm 6.1$ days, comprising $1.1 \pm 2.4$ days in the intensive care unit, $2.5 \pm 2.9$ days in the intermediate or coronary care unit and on average $7.1 \pm 5.3$ days in the general ward. The majority of patients were discharged to a rehabilitation clinic $(43.5 \%)$, while one third of patients $(28.9 \%)$ were discharged home and another quarter of patients were sent back to the referring hospital (24.1\%).

\section{CLINICAL OUTCOMES}

Short-term clinical outcomes within the first 30 days after TAVI are presented in Table 4 (In-hospital clinical outcomes are provided in Online Table 1). Cumulative all-cause mortality was $4.8 \%$. All deaths were due to cardiovascular causes. The overall rate of cerebrovascular accidents after 30 days was 3.3\% with the majority being major strokes $(2.5 \%)$. The myocardial infarction rate was less 
Table 2. Procedural characteristics.

\begin{tabular}{|c|c|c|}
\hline & $\begin{array}{c}\text { All patients } \\
N=697\end{array}$ \\
\hline \multicolumn{2}{|c|}{ Procedure time (min) } & $75.8 \pm 37.9$ \\
\hline \multicolumn{2}{|c|}{ Amount of contrast (ml) } & $215.0 \pm 107.5$ \\
\hline \multicolumn{2}{|c|}{ General anaesthesia, n (\%) } & $380(54.6 \%)$ \\
\hline \multicolumn{2}{|c|}{ Conversion from local to general anaesthesia, n (\%) } & $16(5.1 \%)$ \\
\hline \multirow{3}{*}{$\begin{array}{l}\text { Procedure } \\
\text { location }\end{array}$} & Catheterisation laboratory, n (\%) & $520(74.6 \%)$ \\
\hline & Operating room, n (\%) & $8(1.1 \%)$ \\
\hline & Hybrid room, n (\%) & $169(24.2 \%)$ \\
\hline \multirow{4}{*}{$\begin{array}{l}\text { Access site } \\
\text { location }\end{array}$} & Femoral, n (\%) & $551(79.1 \%)$ \\
\hline & Apical, n (\%) & $126(18.1 \%)$ \\
\hline & Subclavian, n (\%) & $8(1.1 \%)$ \\
\hline & Direct aortic, n (\%) & $12(1.7 \%)$ \\
\hline $\begin{array}{l}\text { Concomitant } \\
\text { procedure }\end{array}$ & $\begin{array}{l}\text { Percutaneous coronary } \\
\text { intervention, } \mathrm{n}(\%)\end{array}$ & $65(9.3 \%)$ \\
\hline \multirow[t]{7}{*}{ Device features } & $\begin{array}{l}\text { Prior balloon aortic } \\
\text { valvuloplasty, } \mathrm{n}(\%)\end{array}$ & $604(86.7 \%)$ \\
\hline & Device implanted & \\
\hline & Medtronic CoreValve, n (\%) & $336(48.4 \%)$ \\
\hline & Edwards SAPIEN XT, n (\%) & $317(45.7 \%)$ \\
\hline & Symetis Acurate, n (\%) & $17(2.4 \%)$ \\
\hline & JenaValve, n (\%) & $23(3.3 \%)$ \\
\hline & SJM Portico, n (\%) & $1(0.1 \%)$ \\
\hline \multirow{4}{*}{$\begin{array}{l}\text { Aortic } \\
\text { regurgitation } \\
\text { post TAVI }\end{array}$} & Grade $0, \mathrm{n}(\%)$ & $170(24.9 \%)$ \\
\hline & Grade $1, \mathrm{n}(\%)$ & $452(66.3 \%)$ \\
\hline & Grade $2, \mathrm{n}(\%)$ & $55(8.1 \%)$ \\
\hline & Grade 3, n (\%) & $5(0.7 \%)$ \\
\hline
\end{tabular}

than $1 \%$. TAVI was effective in symptomatic alleviation (Figure 1) showing a reduction of dyspnoea from $73.1 \%$ of patients in NYHA Class III/IV at baseline to $11.0 \%$ at 30 -day follow-up. Two main subanalyses were performed:

Transvascular (transfemoral and transsubclavian) versus surgical access (transapical and transaortic): baseline and procedural characteristics according to access route are provided in the Online
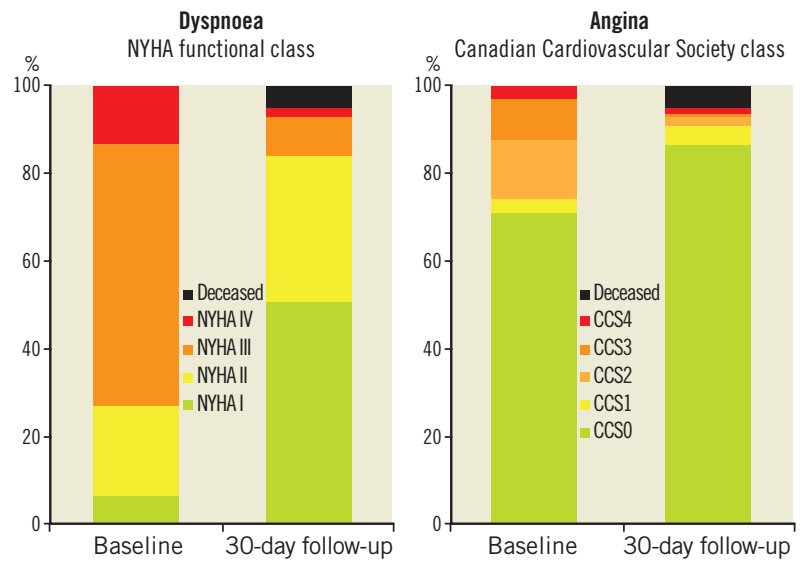

Figure 1. Symptom status at baseline evaluation and at 30-day follow-up after TAVI.
Table 3. In-hospital course.

\begin{tabular}{|c|c|c|}
\hline & $\begin{array}{c}\text { All patients } \\
N=697\end{array}$ \\
\hline \multicolumn{2}{|c|}{ Permanent pacemaker implantation, $\mathrm{n}(\%)$} & 137 (19.9\%) \\
\hline \multicolumn{2}{|c|}{ Any PRBC infusion during hospitalisation, $\mathrm{n}(\%)$} & $131(18.9 \%)$ \\
\hline \multicolumn{2}{|c|}{ Number of PRBC, median (interquartile range) } & $2.0(1.0 ; 3.0)$ \\
\hline \multicolumn{2}{|c|}{ Overall in-hospital stay after TAVI (days) } & $10.7 \pm 6.1$ \\
\hline \multicolumn{2}{|c|}{ Stay at intensive care unit (days) } & $1.1 \pm 2.4$ \\
\hline \multicolumn{2}{|c|}{ Stay at intermediate care (days) } & $2.5 \pm 2.9$ \\
\hline \multicolumn{2}{|c|}{ Stay at general ward (days) } & $7.1 \pm 5.3$ \\
\hline \multirow{5}{*}{$\begin{array}{l}\text { Patient } \\
\text { discharged } \\
\text { to }\end{array}$} & Home, n (\%) & $197(28.9 \%)$ \\
\hline & Referring hospital, n (\%) & $164(24.1 \%)$ \\
\hline & Rehabilitation clinic, n (\%) & $296(43.5 \%)$ \\
\hline & Nursing home, n (\%) & $6(0.9 \%)$ \\
\hline & Other, n (\%) & $18(2.6 \%)$ \\
\hline \multirow[t]{6}{*}{ Medication } & Aspirin exclusive, $\mathrm{n}(\%)$ & $67(10.4 \%)$ \\
\hline & Clopidogrel exclusive, n (\%) & $14(2.2 \%)$ \\
\hline & Oral anticoagulation exclusive, $\mathrm{n}(\%)$ & $54(8.4 \%)$ \\
\hline & Aspirin and clopidogrel, $\mathrm{n}(\%)$ & $355(55.0 \%)$ \\
\hline & Aspirin and oral anticoagulation, n (\%) & $71(11.0 \%)$ \\
\hline & $\begin{array}{l}\text { Clopidogrel and oral anticoagulation, } \\
\mathrm{n}(\%)\end{array}$ & $38(5.9 \%)$ \\
\hline
\end{tabular}

Table 2 and Online Table 3. Clinical outcomes at 30 days of followup are summarised in Table 5. There were no differences with regard to cerebrovascular accidents, myocardial infarction, acute kidney injury and life-threatening bleeding complications between surgical access and transvascular patients; however, vascular access-site and access-related complications ( $0.7 \%$ vs. $14.7 \%$; $\left.\mathrm{HR}_{\text {adjusted }} 0.05,95 \% \mathrm{CI}: 0.01-0.35\right)$ as well as major bleeding complications (3.7\% vs. 9.6\%; HR adjusted $0.33,95 \%$ CI: $0.13-0.84)$ were found to be less frequent among surgical access patients. The

Table 4. Clinical outcomes at 30 days.

\begin{tabular}{|c|c|}
\hline Mortality, $\mathrm{n}(\%)$ & $\begin{array}{c}\text { All patients } \\
\mathrm{N}=697\end{array}$ \\
\hline Cardiovascular mortality, $\mathrm{n}(\%)$ & $33(4.8)$ \\
\hline Cerebrovascular accident, $\mathrm{n}(\%)$ & $33(4.8)$ \\
\hline Major stroke, $\mathrm{n}(\%)$ & $23(3.3)$ \\
\hline Minor stroke, $\mathrm{n}(\%)$ & $17(2.5)$ \\
\hline TIA, $\mathrm{n}(\%)$ & $4(0.6)$ \\
\hline Myocardial infarction, $\mathrm{n}(\%)$ & $2(0.3)$ \\
\hline Spontaneous myocardial infarction, $\mathrm{n}(\%)$ & $3(0.4)$ \\
\hline Bleeding, $\mathrm{n}$ (\%) & $1(0.2)$ \\
\hline Life-threatening bleeding, $\mathrm{n}(\%)$ & $114(16.6)$ \\
\hline Major bleeding, $\mathrm{n}(\%)$ & $43(6.3)$ \\
\hline Minor bleeding, $\mathrm{n}(\%)$ & $58(8.4)$ \\
\hline Permanent pacemaker implanted, $\mathrm{n}(\%)$ & $13(1.9)$ \\
\hline
\end{tabular}


increased rate of permanent pacemaker implantation between surgical access and transvascular treated patients (10.5\% vs. $22.9 \%$; $\mathrm{HR}_{\text {adjusted }} 0.41,95 \% \mathrm{CI}: 0.23-0.72$ ) is mainly explained by differences in device type and design, as permanent pacemaker implantation was found to be less frequent with the Edwards SAPIEN XT when compared with the Medtronic CoreValve. Furthermore, patients with surgical access were at higher risk of death after 30 days compared to patients treated by the transvascular route (Figure 2; 9.5\% vs. 3.6\%; $\mathrm{HR}_{\text {adjusted }} 2.39$, 95\% CI: 1.13-5.04). Comparison of the two most frequently used devices using the transfemoral access only: clinical outcomes at 30 days according to device type are summarised in Table 6. No differences were observed with regard to major cardiac and cerebrovascular events (Figure 3). However, there was an increased risk of vascular accesssite complications when using the Edwards SAPIEN XT prosthesis (19.8\% vs. $11.1 \%$; HR $1.80,95 \%$ CI: $1.16-2.76)$, which was mainly due to major vascular complications (11.7\% vs. 5.6\%; HR 2.12, $95 \% \mathrm{CI}: 1.17-3.84)$. In this patient population, there was no relationship between device size and vascular access-site complications among patients receiving the Edwards SAPIEN XT prosthesis (Online Table 4). In contrast, permanent pacemaker implantation was more frequently required after the implantation of the Medtronic CoreValve prosthesis (11.4\% vs. $31.3 \%$; HR 0.33, $95 \%$ CI: 0.21-0.51).

Additional subgroup analyses revealed a trend of a higher overall mortality among patients undergoing urgent TAVI in comparison with elective procedures (Online Table 5-Online Table 7). Moreover,

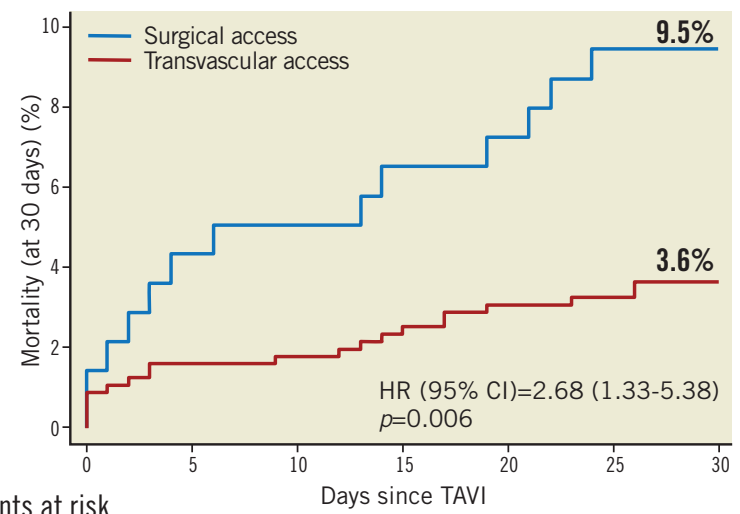

Patients at risk

$\begin{array}{llllllll}\text { TV } & 559 & 545 & 537 & 532 & 526 & 523 & 506 \\ \text { SA } & 138 & 132 & 130 & 128 & 127 & 124 & 121\end{array}$

Figure 2. Cumulative incidence of all-cause mortality among patients undergoing TAVI according to type of access at 30-day follow-up. Of note, surgical access interventions include transapical and direct aortic access patients, and transvascular interventions include transfemoral and subclavian access patients.

patients receiving more than one prosthesis had a comparable outcome apart from a higher incidence of bleeding (Online Table 8-Online Table 10). Finally, patients discharged directly home (28\% of the overall patient population) had very low event rates up to 30 days (mortality: $0 \%$, myocardial infarction: $0.5 \%$, cerebrovascular events: $0.5 \%$ ) (Online Table 11-Online Table 13).

Table 5. Clinical outcomes of surgical and transvascular access patients at $\mathbf{3 0}$ days.

\begin{tabular}{|c|c|c|c|c|c|c|}
\hline & $\begin{array}{l}\text { Surgical access } \\
\qquad N=138\end{array}$ & $\begin{array}{c}\text { Transvascular } \\
\qquad N=559\end{array}$ & $\begin{array}{l}\text { Crude HR or RR } \\
\text { (95\% CI) }\end{array}$ & $p$-value & $\begin{array}{c}\text { Adjusted HR } \\
\text { (95\% CI) }\end{array}$ & $p$-value \\
\hline Mortality, n (\%) & $13(9.5)$ & $20(3.6)$ & $2.68(1.33-5.38)$ & 0.006 & $2.39(1.13-5.04)$ & 0.022 \\
\hline Cardiovascular mortality, n (\%) & $13(9.5)$ & $20(3.6)$ & $2.68(1.33-5.38)$ & 0.006 & $2.39(1.13-5.04)$ & 0.022 \\
\hline Cerebrovascular accident, $n(\%)$ & $5(3.7)$ & $18(3.2)$ & $1.14(0.42-3.06)$ & 0.80 & $1.11(0.39-3.18)$ & 0.85 \\
\hline Major stroke, n (\%) & $5(3.7)$ & $12(2.2)$ & $1.70(0.60-4.82)$ & 0.32 & $1.66(0.54-5.06)$ & 0.37 \\
\hline Minor stroke, n (\%) & $0(0.0)$ & $4(0.7)$ & $0.45(0.02-8.31)$ & 1.00 & & \\
\hline TIA, n (\%) & $0(0.0)$ & $2(0.4)$ & $0.81(0.04-16.78)$ & 1.00 & & \\
\hline Myocardial infarction, n (\%) & $1(0.7)$ & $2(0.4)$ & $2.06(0.19-22.68)$ & 0.56 & $1.46(0.11-18.89)$ & 0.77 \\
\hline Acute kidney injury, n (\%) & $10(7.4)$ & $40(7.3)$ & $1.03(0.51-2.06)$ & 0.94 & $0.94(0.46-1.94)$ & 0.87 \\
\hline Stage $1, n(\%)$ & $4(3.0)$ & $22(4.0)$ & $0.74(0.26-2.16)$ & 0.59 & $0.72(0.24-2.15)$ & 0.55 \\
\hline Stage 2, n (\%) & $3(2.2)$ & $4(0.7)$ & $3.08(0.69-13.78)$ & 0.14 & $2.79(0.55-14.11)$ & 0.22 \\
\hline Stage 3, n (\%) & $3(2.2)$ & $14(2.5)$ & $0.88(0.25-3.06)$ & 0.84 & $0.75(0.21-2.74)$ & 0.66 \\
\hline Bleeding, n (\%) & $16(11.8)$ & $98(17.7)$ & $0.65(0.38-1.10)$ & 0.11 & $0.63(0.37-1.10)$ & 0.10 \\
\hline Life-threatening bleeding, $n(\%)$ & $10(7.4)$ & $33(6.0)$ & $1.24(0.61-2.51)$ & 0.55 & $1.46(0.70-3.04)$ & 0.32 \\
\hline Major bleeding, $n(\%)$ & $5(3.7)$ & $53(9.6)$ & $0.38(0.15-0.94)$ & 0.037 & $0.33(0.13-0.84)$ & 0.02 \\
\hline Minor bleeding, $\mathrm{n}(\%)$ & $1(0.7)$ & $12(2.2)$ & $0.34(0.04-2.62)$ & 0.30 & $0.31(0.04-2.46)$ & 0.23 \\
\hline Vascular access-site complications, n (\%) & $1(0.7)$ & $82(14.7)$ & $0.05(0.01-0.35)$ & 0.003 & $0.05(0.01-0.35)$ & 0.003 \\
\hline Major vascular complications, n (\%) & $0(0.0)$ & $45(8.1)$ & $0.04(0.00-0.65)$ & $<0.001$ & & \\
\hline Minor vascular complications, n (\%) & $1(0.7)$ & $38(6.8)$ & $0.11(0.01-0.78)$ & 0.027 & $0.12(0.02-0.89)$ & 0.038 \\
\hline Permanent pacemaker implantation, $\mathrm{n}(\%)$ & $14(10.5)$ & $126(22.9)$ & $0.43(0.25-0.74)$ & 0.003 & $0.41(0.23-0.72)$ & 0.002 \\
\hline
\end{tabular}




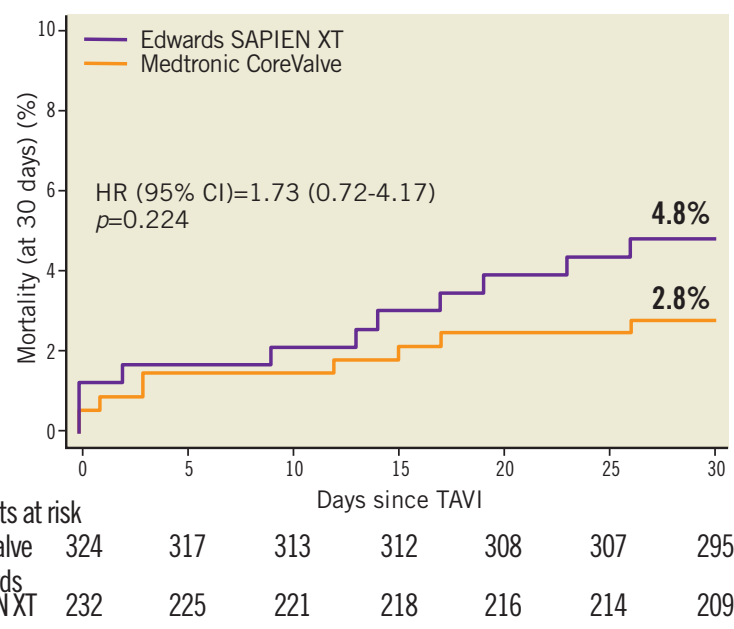

Figure 3. Cumulative incidence of all-cause mortality among patients undergoing transfemoral TAVI according to type of device implanted. Medtronic CoreValve and Edwards SAPIEN XT prosthesis implantations represent $94.1 \%$ of TAVI implantations in Switzerland.

\section{Discussion}

This first report of the Swiss TAVI investigators provides detailed information on in-hospital and 30-day clinical outcomes. The main findings are:

- Carefully selected patients undergoing TAVI with different devices and access routes showed favourable short-term clinical outcomes with lower mortality rates than predicted with the logistic EuroSCORE and the STS risk score.

- Comparison of different access routes suggests a higher risk of all-cause mortality via the transapical or transaortic route even in an adjusted analysis.

- A comparative analysis between the most frequently used devices (Medtronic CoreValve and the Edwards SAPIEN XT) demonstrates no significant difference with respect to mortality, major cardiac or cerebrovascular events. However, there was a threefold increased risk of permanent pacemaker implantation for the Medtronic CoreValve and an almost twofold increased risk of vascular access-site and access-related complications among patients receiving the Edwards SAPIEN XT bioprosthesis.

In this first analysis of the Swiss TAVI registry, the overall 30-day mortality rate remains below the estimated risk using the two most frequently used risk scores for the evaluation of TAVI patients. With an estimated risk of mortality of $8.2 \%$ according to the STS score and $20.2 \%$ according to the logistic EuroSCORE, the risk of TAVI patients in Switzerland is comparable to other European or national registries ${ }^{11-14}$, and confirms the overestimation of periprocedural risk for patient selection in contemporary clinical practice. While the STS score is currently used as the standard risk assessment tool in TAVI trials, the discrepancy between the estimated risk and the observed rate of mortality after a TAVI procedure is still remarkable and highlights the urgent need for a dedicated TAVI risk score for appropriate patient selection.

Table 6. Clinical outcomes among transfemoral patients according to device selection.

\begin{tabular}{|c|c|c|c|c|}
\hline & $\begin{array}{c}\text { Edwards SAPIEN } \\
\text { XT bioprosthesis } \\
\quad N=232\end{array}$ & $\begin{array}{c}\text { Medtronic } \\
\text { CoreValve } \\
\mathrm{N}=324\end{array}$ & $\begin{array}{l}\text { HR or RR } \\
(95 \% \mathrm{CI})\end{array}$ & $p$-value \\
\hline Mortality, n (\%) & $11(4.8)$ & $9(2.8)$ & $1.73(0.72-4.17)$ & 0.22 \\
\hline Cardiovascular mortality, n (\%) & $11(4.8)$ & $9(2.8)$ & $1.73(0.72-4.17)$ & 0.22 \\
\hline Cerebrovascular accident, n (\%) & $9(3.9)$ & $9(2.8)$ & $1.41(0.56-3.55)$ & 0.47 \\
\hline Major stroke, n (\%) & $7(3.0)$ & $5(1.5)$ & $1.97(0.62-6.19)$ & 0.25 \\
\hline Minor stroke, n (\%) & $1(0.4)$ & $3(0.9)$ & $0.47(0.05-4.51)$ & 0.51 \\
\hline TIA, n (\%) & $1(0.4)$ & $1(0.3)$ & $1.41(0.09-22.48)$ & 0.81 \\
\hline Myocardial infarction, n (\%) & $0(0.0)$ & $2(0.6)$ & $0.28(0.01-5.81)$ & 0.51 \\
\hline Acute kidney injury, n (\%) & $14(6.1)$ & $26(8.1)$ & $0.76(0.40-1.46)$ & 0.41 \\
\hline Stage $1, \mathrm{n}(\%)$ & $8(3.5)$ & $14(4.4)$ & $0.81(0.34-1.92)$ & 0.63 \\
\hline Stage 2, n (\%) & $1(0.4)$ & $3(0.9)$ & $0.47(0.05-4.53)$ & 0.51 \\
\hline Stage 3, n (\%) & $5(2.2)$ & $9(2.8)$ & $0.78(0.26-2.34)$ & 0.66 \\
\hline Bleeding, n (\%) & $39(17.0)$ & $58(18.1)$ & $0.95(0.63-1.42)$ & 0.80 \\
\hline Life-threatening bleeding, n (\%) & $12(5.2)$ & $21(6.6)$ & $0.80(0.39-1.62)$ & 0.54 \\
\hline Major bleeding, n (\%) & $26(11.4)$ & $27(8.4)$ & $1.38(0.80-2.36)$ & 0.24 \\
\hline Minor bleeding, $\mathrm{n}(\%)$ & $1(0.4)$ & $10(3.1)$ & $0.14(0.02-1.09)$ & 0.06 \\
\hline Vascular access-site and access-related complications, n (\%) & $46(19.8)$ & $36(11.1)$ & $1.80(1.16-2.78)$ & 0.008 \\
\hline Major vascular complications, $\mathrm{n}(\%)$ & $27(11.7)$ & $18(5.6)$ & $2.12(1.17-3.84)$ & 0.014 \\
\hline Minor vascular complications, $\mathrm{n}(\%)$ & $20(8.6)$ & $18(5.6)$ & $1.55(0.82-2.93)$ & 0.18 \\
\hline Permanent pacemaker implanted, n (\%) & $26(11.4)$ & $100(31.3)$ & $0.33(0.21-0.51)$ & $<0.001$ \\
\hline
\end{tabular}


All deaths within the first 30 days after TAVI were adjudicated to be due to cardiovascular causes, and the rate of $4.8 \%$ compares favourably to the large-scale CoreValve ADVANCE study (4.6\%, 30 -day all-cause mortality $)^{14}$ and the Source registry (8.5\%, 30-day all-cause mortality) ${ }^{13}$, which are considered high-quality databases of contemporary TAVI experience with second-generation devices. While no significant difference was observed for all-cause mortality between the Edwards SAPIEN XT and the Medtronic CoreValve in the transfemoral cohort, there was a significantly higher risk for mortality among patients undergoing TAVI via a surgical access route. This observation was independent of baseline confounders and is consistent with previous reports from the Source registry (transfemoral vs. transapical $4.3 \%$ vs. 9.9\%) ${ }^{13}$, the France 2 registry (transfemoral vs. transapical $8.5 \%$ vs. $13.9 \%, \mathrm{p}<0.001)^{11}$ and the UK TAVI registry (transfemoral vs. other routes $5.5 \%$ vs. $10.7 \%$, $\mathrm{p}=0.006)^{12}$. The reason for this difference is unclear, but is most probably related to the higher risk of patients in the surgical access group. Notably, the majority of TAVI centres in Switzerland follow a "transfemoral first" strategy and the transapical access remains second choice only for patients not eligible to be treated via a transfemoral access. Knowing this, a substantial selection bias to the disadvantage of transapical patients might be mirrored in the results of this report.

The incidence of cerebrovascular accidents in the periprocedural phase after TAVI was comparable to rates reported in other registries. In Germany, periprocedural stroke after TAVI is reported with an incidence rate of 1.7 to $2.3 \%{ }^{15}$, whereas the stroke rates amounted to $3.4 \%$ in France ${ }^{11}, 4.1 \%$ in the UK (in-hospital) ${ }^{12}$, and $5 \%$ in Belgium ${ }^{16}$. In contrast to a recent meta-analysis with more than 10,000 TAVI patients, indicating a decrease in cerebrovascular accidents among patients undergoing transapical TAVI $(2.7 \%$ vs. $4.2 \%)^{17}$, the periprocedural stroke rate was similar among surgical access and transvascular patients in our patient population. A 30-day rate of $3.3 \%$ of cerebrovascular accidents still appears relatively high and requires further action to minimise this risk. Technological improvement, more standardised procedural techniques and cerebral protection during the procedure may help in reducing these disabling adverse events. However, recent studies evaluating cerebral protection devices have so far failed to demonstrate a beneficial effect ${ }^{18}$. Last but not least, alternative antiplatelet and anticoagulation regimens (e.g., bivalirudin) might also be of help in this regard.

In this patient population, the Medtronic CoreValve was associated with a higher risk for permanent pacemaker implantation compared with the Edwards SAPIEN XT prosthesis, corroborating previous reports. Conversely, more vascular access-site complications were observed with the use of the Edwards SAPIEN XT as compared with the Medtronic CoreValve without differences in terms of bleeding. The latter observation is difficult to explain but is possibly related to the larger sheath size (outer diameter) when using the Edwards SAPIEN XT. Other confounding factors like vessel quality, tortuosity and calcification might also have contributed to this difference. Most importantly, the difference in permanent pacemaker implantation or vascular access-site complications did not translate into a higher risk of mortality.

\section{Limitations}

Several limitations need to be acknowledged before interpreting the results of this study. First, as the Swiss TAVI registry was designed to generate data on contemporary clinical practice and outcomes with newer-generation devices in Switzerland, there is no information on the learning curve or the evolution of TAVI devices, procedures or outcomes over time. Second, clinical practice and expertise might be different in the participating centres. Finally, serious adverse event reporting within Swiss TAVI is left to the discretion of each centre and, although the monitoring process includes a systematic plausibility and inconsistency check, we are not able to exclude a certain underreporting of events and bias.

\section{Conclusion}

The Swiss TAVI registry is a prospective, national cohort study assessing clinical outcomes of consecutive patients undergoing TAVI in Switzerland. This first report based on adjudicated events shows favourable short-term clinical outcomes in unselected TAVI patients.

\section{Impact on daily practice}

The Swiss TAVI registry provides favourable clinical outcomes and reflects contemporary clinical practice with CE-approved TAVI devices in patients carefully selected by the Heart Team. The transfemoral route was the preferred access for the majority of patients and was associated with low rates of mortality and cerebrovascular events. However, further improvement of the technology is required to reduce the rate of vascular access-site and bleeding complications.

\section{Funding}

The Swiss TAVI registry is supported by a study grant from the Swiss Heart Foundation and the Swiss Working Group of Interventional Cardiology and Acute Coronary Syndromes, and is sponsored by unrestricted funds from Medtronic, Edwards Lifesciences, Symetis, JenaValve and St. Jude Medical. The study sponsors had no role in study design, data collection, data analysis, data interpretation, or writing of the report.

\section{Conflict of interest statement}

P. Wenaweser has received honoraria and lecture fees from Medtronic and Edwards Lifesciences and has received an unrestricted grant from Medtronic to the institution (University of Bern). F. Nietlispach serves as consultant to Edwards Lifesciences and St. Jude Medical. R. Jeger has received reimbursement for travel expenses from Medtronic, St. Jude Medical and Edwards Lifesciences. E. Ferrari is a proctor for Edwards Lifesciences. S. Toggweiler has received speaker's honoraria from Medtronic. 
T. Carrel has received fees as referee from Medtronic and Edwards Lifesciences. S. Noble serves as consultant for Medtronic. P. Jüni is an unpaid steering committee or statistical executive committee member of trials funded by Abbott Vascular, Biosensors, Medtronic and Johnson \& Johnson. CTU Bern, which is part of the University of Bern, has a staff policy of not accepting honoraria or consultancy fees. However, CTU Bern is involved in design, conduct or analysis of clinical studies funded by Abbott Vascular, Ablynx, Amgen, AstraZeneca, Biosensors, Biotronic, Boehringer Ingelheim, Eisai, Eli Lilly, Exelixis, Geron, Gilead Sciences, Nestlé, Novartis, Novo Nordisc, Padma, Roche, Schering-Plough, St. Jude Medical, and Swiss Cardio Technologies. S. Windecker has received research contracts to the institution from Abbott, Boston Scientific, Biosensors, Cordis, Medtronic and St. Jude. C. Huber is a proctor for Symetis and Edwards Lifesciences, serves as consultant for Medtronic and has shares in Endoheart. All the other authors have no conflicts of interest to declare.

\section{References}

1. Ross J Jr, Braunwald E. Aortic stenosis. Circulation. 1968;38: 61-7.

2. Joint Task Force on the Management of Valvular Heart Disease of the European Society of Cardiology (ESC); European Association for Cardio-Thoracic Surgery (EACTS); Vahanian A, Alfieri O, Andreotti F, Antunes MJ, Baron-Esquivias G, Baumgartner H, Borger MA, Carrel TP, De Bonis M, Evangelista A, Falk V, Iung B, Lancellotti P, Pierard L, Price S, Schafers HJ, Schuler G, Stepinska J, Swedberg K, Takkenberg J, Von Oppell UO, Windecker S, Zamorano JL, Zembala M. Guidelines on the management of valvular heart disease (version 2012). Eur Heart J. 2012;33:2451-96.

3. Cribier A, Eltchaninoff H, Bash A, Borenstein N, Tron C, Bauer F, Derumeaux G, Anselme F, Laborde F, Leon MB. Percutaneous transcatheter implantation of an aortic valve prosthesis for calcific aortic stenosis: first human case description. Circulation. 2002;10:3006-8.

4. Wenaweser P, Pilgrim T, Kadner A, Huber C, Stortecky S, Buellesfeld L, Khattab AA, Meuli F, Roth N, Eberle B, Erdos G, Brinks H, Kalesan B, Meier B, Jüni P, Carrel T, Windecker S. Clinical outcomes of patients with severe aortic stenosis at increased surgical risk according to treatment modality. $J$ Am Coll Cardiol. 2011;58:2151-62.

5. Smith CR, Leon MB, Mack MJ, Miller DC, Moses JW, Svensson LG, Tuzcu EM, Webb JG, Fontana GP, Makkar RR, Williams M, Dewey T, Kapadia S, Babaliaros V, Thourani VH, Corso P, Pichard AD, Bavaria JE, Herrmann HC, Akin JJ, Anderson WN, Wang D, Pocock SJ; PARTNER Trial Investigators. Transcatheter versus surgical aortic-valve replacement in high-risk patients. N Engl J Med. 2011;364:2187-98.

6. Gurvitch R, Wood DA, Tay EL, Leipsic J, Ye J, Lichtenstein SV, Thompson CR, Carere RG, Wijesinghe N, Nietlispach F, Boone RH, Lauck S, Cheung A, Webb JG. Transcatheter aortic valve implantation: durability of clinical and hemodynamic outcomes beyond 3 years in a large patient cohort. Circulation. 2010;122:1319-27.
7. Vahanian A, Alfieri O. Guidelines on valvular heart disease in clinical practice. EuroIntervention. 2013;9:S11-3.

8. Stortecky S, O'Sullivan CJ, Buellesfeld L, Wenaweser P, Windecker S. Transcatheter aortic valve implantation: patient selection. Minerva Cardioangiol. 2013;61:487-97.

9. Leon MB, Piazza N, Nikolsky E, Blackstone EH, Cutlip DE, Kappetein AP, Krucoff MW, Mack M, Mehran R, Miller C, Morel MA, Petersen J, Popma JJ, Takkenberg JJ, Vahanian A, van Es GA, Vranckx P, Webb JG, Windecker S, Serruys PW. Standardized endpoint definitions for transcatheter aortic valve implantation clinical trials: a consensus report from the Valve Academic Research Consortium. Eur Heart J. 2011;32:205-17.

10. Kappetein AP, Head SJ, Généreux P, Piazza N, van Mieghem NM, Blackstone EH, Brott TG, Cohen DJ, Cutlip DE, van Es GA, Hahn RT, Kirtane AJ, Krucoff MW, Kodali S, Mack MJ, Mehran R, Rodés-Cabau J, Vranckx P, Webb JG, Windecker S, Serruys PW, Leon MB; Valve Academic Research Consortium-2. Updated standardized endpoint definitions for transcatheter aortic valve implantation: the Valve Academic Research Consortium-2 consensus document. EuroIntervention.2012;8:782-95.

11. Gilard $\mathrm{M}$, Eltchaninoff $\mathrm{H}$, Iung $\mathrm{B}$, Donzeau-Gouge $\mathrm{P}$, Chevreul K, Fajadet J, Leprince P, Leguerrier A, Lievre M, Prat A, Teiger E, Lefevre T, Himbert D, Tchetche D, Carrie D, Albat B, Cribier A, Rioufol G, Sudre A, Blanchard D, Collet F, Dos Santos P, Meneveau N, Tirouvanziam A, Caussin C, Guyon P, Boschat J, Le Breton H, Collart F, Houel R, Delpine S, Souteyrand G, Favereau X, Ohlmann P, Doisy V, Grollier G, Gommeaux A, Claudel JP, Bourlon F, Bertrand B, Van Belle E, Laskar M; FRANCE 2 Investigators. Registry of transcatheter aortic-valve implantation in high-risk patients. $N$ Engl J Med. 2012;366:1705-15.

12. Moat NE, Ludman P, de Belder MA, Bridgewater B, Cunningham AD, Young CP, Thomas M, Kovac J, Spyt T, MacCarthy PA, Wendler O, Hildick-Smith D, Davies SW, Trivedi U, Blackman DJ, Levy RD, Brecker SJ, Baumbach A, Daniel T, Gray H, Mullen MJ. Long-term outcomes after transcatheter aortic valve implantation in high-risk patients with severe aortic stenosis: the U.K. TAVI (United Kingdom Transcatheter Aortic Valve Implantation) Registry. J Am Coll Cardiol. 2011;58:2130-8.

13. Thomas M, Schymik G, Walther T, Himbert D, Lefèvre T, Treede H, Eggebrecht H, Rubino P, Michev I, Lange R, Anderson WN, Wendler O. Thirty-day results of the SAPIEN aortic Bioprosthesis European Outcome (SOURCE) Registry: A European registry of transcatheter aortic valve implantation using the Edwards SAPIEN valve. Circulation. 2010;122:62-9.

14. Linke A, Gerckens U, Wenaweser P, Tamburino C, Bosmans J, Brecker S, Bauernschmitt R. Treatment of high risk aortic stenosis patients with transcatheter Medtronic CoreValve Implantation: Results from the International multi-center Advance Study. $\mathrm{J} \mathrm{Am}$ Coll Cardiol. 2012;59:E8-E8.

15. Hamm CW, Mollmann H, Holzhey D, Beckmann A, Veit C, Figulla HR, Cremer J, Kuck KH, Lange R, Zahn R, Sack S, Schuler G, Walther T, Beyersdorf F, Bohm M, Heusch G, Funkat AK, Meinertz T, Neumann T, Papoutsis K, Schneider S, Welz A, 
Mohr FW; for the GARY-Executive Board. The German Aortic Valve Registry (GARY): in-hospital outcome. Eur Heart J. 2013 Sep 10. [Epub ahead of print].

16. Bosmans JM, Kefer J, De Bruyne B, Herijgers P, Dubois C, Legrand V, Verheye S, Rodrigus I; Belgian TAVI Registry Participants. Procedural, 30-day and one year outcome following CoreValve or Edwards transcatheter aortic valve implantation: results of the Belgian national registry. Interact Cardiovasc Thorac Surg. 2011;12:762-7.

17. Eggebrecht H, Schmermund A, Voigtlander T, Kahlert P, Erbel R, Mehta RH. Risk of stroke after transcatheter aortic valve implantation (TAVI): a meta-analysis of 10,037 published patients. EuroIntervention. 2012;8:129-38.

18. Praz F, Nietlispach F. Cerebral protection devices for transcatheter aortic valve implantation: is better the enemy of good? EuroIntervention. 2013;9:S124-8.

\section{Online data supplement}

Online Appendix. Collaborators and Swiss TAVI investigators. Online Table 1. In-hospital clinical outcomes.

Online Table 2. Baseline surgical vs. transvascular access.

Online Table 3. Procedure surgical vs. transvascular access. Online Table 4. Access complications according to Edwards SAPIEN XT size.

Online Table 5. Baseline urgent vs. elective treatment. Online Table 6. Procedure urgent vs. elective treatment. Online Table 7. Outcomes urgent vs. elective treatment. Online Table 8. Baseline one vs. more than one prosthesis. Online Table 9. Procedure one vs. more than one prosthesis. Online Table 10. Outcomes one vs. more than one prosthesis. Online Table 11. Baseline discharge home vs. others.

Online Table 12. Procedure discharge home vs. others. Online Table 13. Outcomes discharge home vs. others. 


\section{Online data supplement}

\section{Online Appendix. Collaborators and Swiss TAVI Investigators}

University Hospital Basel

Department of Cardiology: Raban Jeger, MD; Christoph Kaiser, MD

Department of Cardiothoracic Surgery: Oliver Reuthebuch, MD

\section{University Hospital Bern}

Department of Cardiology: Peter Wenaweser, MD; Stefan

Stortecky, MD; Lorenz Räber, MD; Stephan Windecker, MD;

Saskia Dunkel de-Raad, PhD

Department of Cardiothoracic Surgery: Christoph Huber, MD;

Thierry Carrel, MD

\section{Department of Clinical Research}

Clinical Trials Unit, University of Bern: Peter Jüni, MD; Dik Heg, PhD; Nico Pfäffli; Serge Zaugg

\section{University Hospital Geneva}

Department of Cardiology: Marco Roffi, MD; Stephane Noble, MD

Department of Cardiothoracic Surgery: Mustafa Cikirikcioglu, MD

\section{University Hospital Lausanne}

Department of Cardiology: Didier Locca, MD

Department of Cardiothoracic Surgery: Enrico Ferrari, MD

\section{Cantonal Hospital Lucerne}

Department of Cardiology: Stefan Toggweiler, MD

Department of Cardiothoracic Surgery: Xavier Mueller, MD

\section{Cardiocentro Ticino, Lugano}

Department of Cardiology: Giovanni Pedrazzini, MD

Department of Cardiothoracic Surgery: Stefano Demertzis, MD

\section{Triemli Hospital Zurich}

Department of Cardiology: David Tüller, MD; Franz Eberli, MD

Department of Cardiothoracic Surgery: Michele Genoni, MD;

Omer Dzemali, MD

\section{Hirslanden Clinic Zurich}

\section{Klinik im Park}

Department of Cardiology: Franz W. Amann, MD

Department of Cardiothoracic Surgery: Pascal A. Berdat, MD

\section{Hirslanden Cardiac Centre Zurich}

Department of Cardiology: Gabor Sütsch, MD

Department of Cardiothoracic Surgery: Franziska Bernet, MD

\section{Heart Clinic Hirslanden}

Department of Cardiology: Roberto Corti, MD

Department of Cardiothoracic Surgery: Jürg Grünenfelder, MD
University Hospital Zurich

Department of Cardiology: Fabian Nietlispach, MD; Ronald

Binder, MD

Department of Cardiothoracic Surgery: Volkmar Falk, MD;

Francesco Maisano, MD

Department of Anaesthesiology: Dominique Bettex, MD

\section{St Clara's Hospital Basel}

Department of Cardiology: Lukas Altwegg, MD (prior member of the SC)

Online Table 1. In-hospital clinical outcomes.

\begin{tabular}{|c|c|}
\hline In-hospital clinical outcomes & $\begin{array}{l}\text { All patients } \\
\quad N=697\end{array}$ \\
\hline Mortality, n (\%) & $22(3.2)$ \\
\hline Cardiovascular mortality, $\mathrm{n}(\%)$ & $22(3.2)$ \\
\hline Cerebrovascular accident, n (\%) & $22(3.2)$ \\
\hline Major stroke, n (\%) & $17(2.4)$ \\
\hline Minor stroke, n (\%) & $3(0.4)$ \\
\hline TIA, n (\%) & $2(0.3)$ \\
\hline Myocardial infarction, n (\%) & $2(0.3)$ \\
\hline Periprocedural myocardial infarction, $\mathrm{n}(\%)$ & $2(0.3)$ \\
\hline Acute kidney injury, $\mathrm{n}(\%)$ & $49(7.0)$ \\
\hline Stage $1, \mathrm{n}(\%)$ & $26(3.7)$ \\
\hline Stage $2, \mathrm{n}(\%)$ & $7(1.0)$ \\
\hline Stage 3, n (\%) & $16(2.3)$ \\
\hline Bleeding, n (\%) & $105(15.1)$ \\
\hline Life-threatening bleeding, $\mathrm{n}(\%)$ & $37(5.3)$ \\
\hline Major bleeding, n (\%) & $56(8.0)$ \\
\hline Minor bleeding, n (\%) & $12(1.7)$ \\
\hline $\begin{array}{l}\text { Vascular access-site and access-related } \\
\text { complications, } \mathrm{n}(\%)\end{array}$ & $82(11.8)$ \\
\hline Major vascular complications, $\mathrm{n}(\%)$ & $44(6.3)$ \\
\hline Minor vascular complications, $\mathrm{n}(\%)$ & $39(5.6)$ \\
\hline Permanent pacemaker implanted, $\mathrm{n}(\%)$ & $137(19.7)$ \\
\hline \multicolumn{2}{|c|}{$\begin{array}{l}\text { Depicted are number of first events with \% of all patients (in-hospital } \\
\text { events). All clinical outcomes were adjudicated. }\end{array}$} \\
\hline
\end{tabular}


Online Table 2. Baseline surgical vs. transvascular access.

\begin{tabular}{|c|c|c|c|c|c|}
\hline & \multicolumn{4}{|c|}{$\begin{array}{l}\text { Baseline characteristics of surgical access vs. transvascular access } \\
\text { patients }\end{array}$} \\
\hline & & $\begin{array}{c}\text { Surgical access } \\
\mathrm{N}=138\end{array}$ & $\begin{array}{l}\text { Transvascular } \\
\quad \mathrm{N}=559\end{array}$ & $\begin{array}{l}\text { Difference } \\
(95 \% \mathrm{CI})\end{array}$ & $p$-value \\
\hline \multicolumn{2}{|l|}{ Age (years) } & $81.6 \pm 5.8$ & $82.6 \pm 6.2$ & $-1.0(-2.2 ; 0.2)$ & 0.088 \\
\hline \multicolumn{2}{|c|}{ Female gender, n (\%) } & $66(47.8 \%)$ & $293(52.4 \%)$ & $-4.6 \%(-13.9 \% ; 4.7 \%)$ & 0.34 \\
\hline \multicolumn{2}{|c|}{ Body mass index $\left(\mathrm{kg} / \mathrm{m}^{2}\right)$} & $26.2 \pm 4.8$ & $26.3 \pm 5.0$ & $-0.14(-1.1 ; 0.8)$ & 0.76 \\
\hline \multirow{3}{*}{$\begin{array}{l}\text { Cardiac risk } \\
\text { factors }\end{array}$} & Diabetes mellitus, n (\%) & $42(30.4 \%)$ & $162(29.0 \%)$ & $-1.5 \%(-10.0 \% ; 7.0 \%)$ & 0.75 \\
\hline & Dyslipidaemia, n (\%) & $80(58.0 \%)$ & $307(54.9 \%)$ & $-3.1 \%(-12.3 \% ; 6.2 \%)$ & 0.57 \\
\hline & Hypertension, n (\%) & $119(86.2 \%)$ & $455(81.4 \%)$ & $-4.8 \%(-12.0 \% ; 2.3 \%)$ & 0.21 \\
\hline \multirow{4}{*}{$\begin{array}{l}\text { Past medical } \\
\text { history }\end{array}$} & Previous pacemaker implantation, n (\%) & $11(8.0 \%)$ & $58(10.4 \%)$ & $2.4 \%(-3.2 \% ; 8.0 \%)$ & 0.52 \\
\hline & Previous myocardial infarction, n (\%) & $22(15.9 \%)$ & $83(14.8 \%)$ & $-1.1 \%(-7.8 \% ; 5.6 \%)$ & 0.79 \\
\hline & Previous cardiac surgery, $\mathrm{n}(\%)$ & $34(24.6 \%)$ & $70(12.5 \%)$ & $-12.1 \%(-18.7 \% ;-5.5 \%)$ & 0.001 \\
\hline & Previous stroke, n (\%) & $17(12.3 \%)$ & $66(11.8 \%)$ & $-0.5 \%(-6.6 \% ; 5.5 \%)$ & 0.88 \\
\hline \multirow[t]{6}{*}{ Clinical features } & Peripheral vascular disease, $\mathrm{n}(\%)$ & $58(42.0 \%)$ & $79(14.1 \%)$ & $-27.9 \%(-35.0 \% ;-20.8 \%)$ & $<0.001$ \\
\hline & Chronic obstructive pulmonary disease, n (\%) & $25(18.1 \%)$ & $84(15.0 \%)$ & $-3.1 \%(-9.9 \% ; 3.7 \%)$ & 0.36 \\
\hline & Coronary artery disease, n (\%) & $96(69.6 \%)$ & $294(52.6 \%)$ & $-17.0 \%(-26.2 \% ;-7.8 \%)$ & $<0.001$ \\
\hline & Left ventricular ejection fraction (\%) & $52.4 \pm 14.3$ & $54.2 \pm 14.1$ & $-1.88(-5.0 ; 1.2)$ & 0.23 \\
\hline & Aortic valve area $\left(\mathrm{cm}^{2}\right)$ & $0.7 \pm 0.3$ & $0.74 \pm 0.3$ & $-0.01(-0.07 ; 0.05)$ & 0.70 \\
\hline & Mean transaortic gradient $(\mathrm{mmHg})$ & $45.5 \pm 19.8$ & $44.7 \pm 16.7$ & $0.82(-2.97 ; 4.61)$ & 0.67 \\
\hline \multirow[t]{2}{*}{ Risk assessment } & Log. EuroSCORE (\%) & $22.5 \pm 13.1$ & $19.6 \pm 12.5$ & $2.89(0.13 ; 5.66)$ & 0.04 \\
\hline & STS score (\%) & $9.0 \pm 7.8$ & $8.0 \pm 7.0$ & $0.92(-0.41 ; 2.25)$ & 0.18 \\
\hline
\end{tabular}


Online Table 3. Procedure surgical vs. transvascular access.

\begin{tabular}{|c|c|c|c|c|}
\hline & \multicolumn{4}{|c|}{ Procedural characteristics surgical access vs. transvascular access patients } \\
\hline & $\begin{array}{c}\text { Surgical access } \\
\mathrm{N}=138\end{array}$ & $\begin{array}{c}\text { Transvascular } \\
N=559\end{array}$ & $\begin{array}{l}\text { Difference } \\
(95 \% \mathrm{CI})\end{array}$ & p-value \\
\hline Procedure time $(\mathrm{min})$ & $83.3 \pm 41.4$ & $73.9 \pm 36.8$ & $9.4(2.2 ; 16.6)$ & 0.011 \\
\hline Amount of contrast (ml) & $192.0 \pm 91.2$ & $220.0 \pm 110$ & $-28.0(-49.4 ;-6.6)$ & 0.010 \\
\hline General anaesthesia, $\mathrm{n}(\%)$ & $138(100.0 \%)$ & $242(43.4 \%)$ & $56.6 \%(48.3 \% ; 64.9 \%)$ & $<0.001$ \\
\hline Procedure location & & & & $<0.001$ \\
\hline Catheterisation laboratory, n (\%) & $95(68.8 \%)$ & $425(76.0 \%)$ & $-7.2 \%(-15.3 \% ; 0.9 \%)$ & \\
\hline Operating room, $\mathrm{n}(\%)$ & $7(5.1 \%)$ & $1(0.2 \%)$ & $4.9 \%(2.9 \% ; 6.9 \%)$ & \\
\hline Hybrid room, n (\%) & $36(26.1 \%)$ & $133(23.8 \%)$ & $2.3 \%(-5.7 \% ; 0.3 \%)$ & \\
\hline \multicolumn{5}{|l|}{ Concomitant procedure } \\
\hline Percutaneous coronary intervention, $\mathrm{n}(\%)$ & $7(5.1 \%)$ & $58(10.4 \%)$ & $5.3 \%(-0.1 \% ; 10.7 \%)$ & 0.071 \\
\hline \multicolumn{5}{|l|}{ Device features } \\
\hline Prior balloon aortic valvuloplasty, $\mathrm{n}(\%)$ & $129(93.5 \%)$ & $475(85.0 \%)$ & $-8.5 \%(-14.8 \% ;-2.2 \%)$ & 0.008 \\
\hline Device implanted & & & & $<0.001$ \\
\hline Medtronic CoreValve, n (\%) & $12(8.8 \%)$ & $324(58.2 \%)$ & $-49.4 \%(-58.0 \% ;-40.8 \%)$ & \\
\hline Edwards SAPIEN XT, n (\%) & $85(62.0 \%)$ & $232(41.7 \%)$ & $20.4 \%(11.2 \% ; 29.6 \%)$ & \\
\hline Symetis Acurate, n (\%) & $17(12.4 \%)$ & $0(0.0 \%)$ & $12.4 \%(9.7 \% ; 15.2 \%)$ & \\
\hline JenaValve, $\mathrm{n}(\%)$ & $23(16.8 \%)$ & $0(0.0 \%)$ & $16.8 \%(13.7 \% ; 19.9 \%)$ & \\
\hline SJM Portico, n (\%) & $0(0.0 \%)$ & $1(0.2 \%)$ & $-0.2 \%(-0.9 \% ; 0.5 \%)$ & \\
\hline Aortic regurgitation post TAVI & & & & 0.24 \\
\hline Grade 0, n (\%) & $40(29.6 \%)$ & $130(23.8 \%)$ & $5.9 \%(-2.3 \% ; 14.0 \%)$ & \\
\hline Grade $1, \mathrm{n}(\%)$ & $88(65.2 \%)$ & $364(66.5 \%)$ & $-1.4 \%(-10.3 \% ; 7.6 \%)$ & \\
\hline Grade 2, n (\%) & $6(4.4 \%)$ & $49(9.0 \%)$ & $-4.5 \%(-9.6 \% ; 0.6 \%)$ & \\
\hline Grade 3, n (\%) & $1(0.7 \%)$ & $4(0.7 \%)$ & $0.0 \%(-1.6 \% ; 1.6 \%)$ & \\
\hline \multicolumn{5}{|l|}{ In-hospital course } \\
\hline Permanent pacemaker implantation, n (\%) & $12(8.8 \%)$ & $125(22.7 \%)$ & $13.9 \%(6.5 \% ; 21.4 \%)$ & $<0.001$ \\
\hline $\begin{array}{l}\text { Any packed red blood cell infusion during hospitalisation, } \\
\mathrm{n}(\%)\end{array}$ & $36(26.1 \%)$ & $95(17.1 \%)$ & $-9.0 \%(-16.3 \% ;-1.7 \%)$ & 0.021 \\
\hline Number of PRBC, median (interquartile range) & $2.0(1.0 ; 3.0)$ & $2.0(1.0 ; 3.0)$ & $-0.58(-2.05 ; 0.89)$ & 0.51 \\
\hline Overall in-hospital stay after TAVI (days) & $11.1 \pm 5.1$ & $10.6 \pm 6.4$ & $0.48(-0.68 ; 1.63)$ & 0.42 \\
\hline Stay at intensive care unit (days) & $2.0 \pm 1.9$ & $0.9 \pm 2.4$ & $1.03(0.59 ; 1.46)$ & $<0.001$ \\
\hline Stay at intermediate care (days) & $1.1 \pm 2.4$ & $2.9 \pm 3.0$ & $-1.75(-2.29 ;-1.22)$ & $<0.001$ \\
\hline Stay at general ward (days) & $8.1 \pm 4.4$ & $6.9 \pm 5.5$ & $1.20(0.20 ; 2.20)$ & 0.019 \\
\hline Patient discharged to & & & & 0.001 \\
\hline Home, n (\%) & $30(22.2 \%)$ & $167(30.6 \%)$ & $-8.4 \%(-16.9 \% ; 0.2 \%)$ & \\
\hline Referring hospital, n (\%) & $23(17.0 \%)$ & $141(25.8 \%)$ & $-8.8 \%(-16.8 \% ;-0.7 \%)$ & \\
\hline Rehabilitation clinic, n (\%) & $74(54.8 \%)$ & $222(40.7 \%)$ & $14.2 \%(4.8 \% ; 23.5 \%)$ & \\
\hline Nursing home, $\mathrm{n}(\%)$ & $0(0.0 \%)$ & $6(1.1 \%)$ & $-1.1 \%(-2.9 \% ; 0.7 \%)$ & \\
\hline Other, n (\%) & $8(5.9 \%)$ & $10(1.8 \%)$ & $4.1 \%(1.1 \% ; 7.1 \%)$ & \\
\hline
\end{tabular}


Online Table 4. Access complications according to Edwards SAPIEN XT size.

Vascular access-site complications according to device size among transfemoral access patients with the Edwards SAPIEN XT prosthesis

\begin{tabular}{|c|c|c|c|c|}
\hline $\begin{array}{c}23 \mathrm{~mm} \\
\mathrm{~N}=68\end{array}$ & $\begin{array}{l}26 \mathrm{~mm} \\
\mathrm{~N}=142\end{array}$ & $\begin{array}{c}29 \mathrm{~mm} \\
\mathrm{~N}=21\end{array}$ & $\begin{array}{c}\text { HR } \\
(95 \% \text { Cl) }\end{array}$ & $p$-value \\
\hline
\end{tabular}

\section{0-day follow-up - events}

\begin{tabular}{|c|c|c|c|c|c|}
\hline Vascular access-site complications, $\mathrm{n}(\%)$ & $14(20.6)$ & $29(20.4)$ & $3(14.3)$ & $0.90(0.55-1.47)$ & 0.67 \\
\hline Major vascular complications, $\mathrm{n}(\%)$ & $7(10.3)$ & $18(12.7)$ & $2(9.5)$ & $1.05(0.55-2.00)$ & 0.88 \\
\hline Minor vascular complications, $\mathrm{n}(\%)$ & $7(10.3)$ & $12(8.5)$ & $1(4.8)$ & $0.75(0.35-1.60)$ & 0.46 \\
\hline
\end{tabular}

Depicted are number of first events censored at 30 days since procedure with \% from Kaplan-Meier estimates. ${ }^{*} \mathrm{n}: 1$ patient with Edwards device size of $20 \mathrm{~mm}$ not shown. Hazard ratio (HR; with 95\% confidence intervals) from Cox's regression with a $p$-value testing a linear effect from $23 \mathrm{~mm}$ (set as reference) to $29 \mathrm{~mm}$.

Online Table 5. Baseline urgent vs. elective treatment.

\begin{tabular}{|c|c|c|c|c|c|}
\hline & \multicolumn{4}{|c|}{ Baseline characteristics of urgent vs. elective patients } \\
\hline & & $\begin{array}{l}\text { Urgent } \\
N=35\end{array}$ & $\begin{array}{l}\text { Elective } \\
N=657\end{array}$ & $\begin{array}{l}\text { Difference } \\
\text { (95\% CI) }\end{array}$ & $p$-value \\
\hline \multicolumn{2}{|l|}{ Age (years) } & $82.6 \pm 6.0$ & $82.4 \pm 6.2$ & $0.2(-1.9 ; 2.3)$ & 0.85 \\
\hline \multicolumn{2}{|c|}{ Female gender, $\mathrm{n}(\%)$} & $19(54.3 \%)$ & $338(51.4 \%)$ & $2.8 \%(-14.2 \% ; 19.9 \%)$ & 0.86 \\
\hline \multicolumn{2}{|c|}{ Body mass index $\left(\mathrm{kg} / \mathrm{m}^{2}\right)$} & $26.0 \pm 5.2$ & $26.4 \pm 5.0$ & $-0.3(-2.0 ; 1.4)$ & 0.70 \\
\hline \multirow{3}{*}{$\begin{array}{l}\text { Cardiac risk } \\
\text { factors }\end{array}$} & Diabetes mellitus, n (\%) & $12(34.3 \%)$ & $192(29.2 \%)$ & $-5.1 \%(-20.6 \% ; 10.5 \%)$ & 0.57 \\
\hline & Dyslipidaemia, n (\%) & $19(54.3 \%)$ & $366(55.7 \%)$ & $1.4 \%(-15.5 \% ; 18.4 \%)$ & 0.86 \\
\hline & Hypertension, n (\%) & $28(80.0 \%)$ & $542(82.5 \%)$ & $2.5 \%(-10.5 \% ; 15.5 \%)$ & 0.65 \\
\hline \multirow{4}{*}{$\begin{array}{l}\text { Past medical } \\
\text { history }\end{array}$} & Previous pacemaker implantation, $\mathrm{n}(\%)$ & $1(2.9 \%)$ & $67(10.2 \%)$ & $7.3 \%(-2.8 \% ; 17.5 \%)$ & 0.24 \\
\hline & Previous myocardial infarction, n (\%) & $6(17.1 \%)$ & $98(14.9 \%)$ & $-2.2 \%(-14.4 \% ; 10.0 \%)$ & 0.63 \\
\hline & Previous cardiac surgery, $\mathrm{n}(\%)$ & $3(8.6 \%)$ & $101(15.4 \%)$ & $6.8 \%(-5.4 \% ; 19.0 \%)$ & 0.34 \\
\hline & Previous stroke, n (\%) & $3(8.6 \%)$ & $80(12.2 \%)$ & $3.6 \%(-7.5 \% ; 14.7 \%)$ & 0.79 \\
\hline \multirow[t]{6}{*}{ Clinical features } & Peripheral vascular disease, n (\%) & $5(14.3 \%)$ & $130(19.8 \%)$ & $5.5 \%(-8.0 \% ; 19.0 \%)$ & 0.52 \\
\hline & Chronic obstructive pulmonary disease, $\mathrm{n}(\%)$ & $4(11.4 \%)$ & $103(15.7 \%)$ & $4.2 \%(-8.1 \% ; 16.6 \%)$ & 0.64 \\
\hline & Coronary artery disease, n (\%) & $24(68.6 \%)$ & $365(55.6 \%)$ & $-13.0 \%(-29.9 \% ; 3.9 \%)$ & 0.16 \\
\hline & Left ventricular ejection fraction (\%) & $46.9 \pm 17.6$ & $54.2 \pm 13.8$ & $-7.4(-12.9 ;-1.8)$ & 0.01 \\
\hline & Aortic valve area $\left(\mathrm{cm}^{2}\right)$ & $0.7 \pm 0.2$ & $0.7 \pm 0.3$ & $-0.06(-0.17 ; 0.04)$ & 0.22 \\
\hline & Mean transaortic gradient $(\mathrm{mmHg})$ & $44.1 \pm 18.6$ & $44.8 \pm 17.4$ & $-0.7(-7.6 ; 6.2)$ & 0.84 \\
\hline \multirow[t]{2}{*}{ Risk assessment } & Log. EuroSCORE (\%) & $29.2 \pm 19.8$ & $19.4 \pm 11.6$ & $9.8(5.5 ; 14.0)$ & $<0.001$ \\
\hline & STS score (\%) & $12.1 \pm 9.7$ & $8.0 \pm 6.9$ & $4.1(1.7 ; 6.5)$ & 0.001 \\
\hline
\end{tabular}


Online Table 6. Procedure urgent vs. elective treatment.

\begin{tabular}{|c|c|c|c|c|}
\hline & \multicolumn{4}{|c|}{ Procedural characteristics of urgent vs. elective patients } \\
\hline & Urgent $N=35$ & Elective $N=657$ & Difference (95\% CI) & $p$-value \\
\hline Procedure time $(\mathrm{min})$ & $76.3 \pm 31.0$ & $76.0 \pm 38.2$ & $0.4(-14.0 ; 14.8)$ & 0.96 \\
\hline Amount of contrast (ml) & $221.1 \pm 87.8$ & $214.4 \pm 108.4$ & $6.7(-31.5 ; 45.0)$ & 0.73 \\
\hline General anaesthesia, n (\%) & $11(31.4 \%)$ & $365(55.6 \%)$ & $-24.2 \%(-41.1 \% ;-7.3 \%)$ & 0.008 \\
\hline Conversion from local to general anaesthesia, n (\%) & $3(12.5 \%)$ & $13(4.5 \%)$ & $-8.0 \%(-17.2 \% ; 1.1 \%)$ & 0.11 \\
\hline Procedure location & & & & 0.007 \\
\hline Catheterisation laboratory, $\mathrm{n}(\%)$ & $34(97.1 \%)$ & $481(73.2 \%)$ & $23.9 \%(9.2 \% ; 38.7 \%)$ & \\
\hline Operating room, $\mathrm{n}(\%)$ & $0(0.0 \%)$ & $8(1.2 \%)$ & $-1.2 \%(-4.9 \% ; 2.4 \%)$ & \\
\hline Hybrid room, n (\%) & $1(2.9 \%)$ & $168(25.6 \%)$ & $-22.7 \%(-37.3 \% ;-8.2 \%)$ & \\
\hline Access-site location & & & & 0.67 \\
\hline Femoral & $30(85.7 \%)$ & $517(78.7 \%)$ & $7.0 \%(-6.8 \% ; 20.9 \%)$ & \\
\hline Transapical & $5(14.3 \%)$ & $120(18.3 \%)$ & $-4.0 \%(-17.1 \% ; 9.1 \%)$ & \\
\hline Subclavian & $0(0.0 \%)$ & $8(1.2 \%)$ & $-1.2(-4.9 \% ; 2.4 \%)$ & \\
\hline Direct aortic & $0(0.0 \%)$ & $12(1.8 \%)$ & $-1.8 \%(-6.3 \% ; 2.6 \%)$ & \\
\hline \multicolumn{5}{|l|}{ Concomitant procedure } \\
\hline Percutaneous coronary intervention, $\mathrm{n}(\%)$ & $7(20.0 \%)$ & $57(8.7 \%)$ & $-11.3 \%(-21.2 \% ;-1.5 \%)$ & 0.035 \\
\hline \multicolumn{5}{|l|}{ Device features } \\
\hline Prior balloon aortic valvuloplasty, $\mathrm{n}(\%)$ & $31(88.6 \%)$ & $568(86.5 \%)$ & $-2.1 \%(-13.8 \% ; 9.5 \%)$ & 1.00 \\
\hline Device implanted & & & & 0.56 \\
\hline Medtronic CoreValve, n (\%) & $18(51.4 \%)$ & $314(48.0 \%)$ & $3.4 \%(-13.6 \% ; 20.5 \%)$ & \\
\hline Edwards SAPIEN XT, n (\%) & $15(42.9 \%)$ & $301(46.0 \%)$ & $-3.2 \%(-20.2 \% ; 13.8 \%)$ & \\
\hline Symetis Acurate, n (\%) & $2(5.7 \%)$ & $15(2.3 \%)$ & $3.4 \%(-1.9 \% ; 8.7 \%)$ & \\
\hline JenaValve, n (\%) & $0(0.0 \%)$ & $23(3.5 \%)$ & $-3.5 \%(-9.6 \% ; 2.6 \%)$ & \\
\hline SJM Portico, n (\%) & $0(0.0 \%)$ & $1(0.2 \%)$ & $-0.2 \%(-1.5 \% ; 1.1 \%)$ & \\
\hline Aortic regurgitation post TAVI & & & & 0.96 \\
\hline Grade $0, \mathrm{n}(\%)$ & $8(22.9 \%)$ & $161(25.1 \%)$ & $-2.2 \%(-17.0 \% ; 12.5 \%)$ & \\
\hline Grade $1, \mathrm{n}(\%)$ & $24(68.6 \%)$ & $425(66.2 \%)$ & $2.4 \%(-13.8 \% ; 18.5 \%)$ & \\
\hline Grade 2, n (\%) & $3(8.6 \%)$ & $52(8.1 \%)$ & $0.5 \%(-8.9 \% ; 9.8 \%)$ & \\
\hline Grade 3, n (\%) & $0(0.0 \%)$ & $4(0.6 \%)$ & $-0.6 \%(-3.2 \% ; 2.0 \%)$ & \\
\hline \multicolumn{5}{|l|}{ In-hospital course } \\
\hline Permanent pacemaker implantation, n (\%) & $4(11.4 \%)$ & $133(20.4 \%)$ & $8.9 \%(-4.7 \% ; 22.5 \%)$ & 0.28 \\
\hline Any packed red blood cell during hospitalisation, $\mathrm{n}(\%)$ & $11(31.4 \%)$ & $116(17.8 \%)$ & $-13.7 \%(-26.9 \% ;-0.5 \%)$ & 0.069 \\
\hline Number of PRBC, median (interquartile range) & $1.0(1.0 ; 3.0)$ & $2.0(1.0 ; 3.0)$ & $-1.1(-3.7 ; 1.5)$ & 0.11 \\
\hline Overall in-hospital stay after TAVI (days) & $12.7 \pm 9.3$ & $10.6 \pm 5.9$ & $2.0(-0.06 ; 4.1)$ & 0.057 \\
\hline Stay at intensive care unit (days) & $1.5 \pm 2.6$ & $1.1 \pm 2.3$ & $0.4(-0.5 ; 1.2)$ & 0.39 \\
\hline Stay at intermediate care (days) & $3.5 \pm 4.1$ & $2.5 \pm 2.9$ & $0.9(-0.08 ; 1.9)$ & 0.072 \\
\hline Stay at general ward (days) & $7.8 \pm 8.8$ & $7.1 \pm 5.1$ & $0.8(-1.1 ; 2.6)$ & 0.41 \\
\hline Patient discharged to & & & & $<0.001$ \\
\hline Home, n (\%) & $6(18.2 \%)$ & $191(29.5 \%)$ & $-11.3 \%(-27.2 \% ; 4.6 \%)$ & \\
\hline Referring hospital, n (\%) & $14(42.4 \%)$ & $150(23.1 \%)$ & $19.3 \%(4.3 \% ; 34.2 \%)$ & \\
\hline Rehabilitation clinic, n (\%) & $9(27.3 \%)$ & $287(44.3 \%)$ & $-17.0 \%(-34.4 \% ; 0.3 \%)$ & \\
\hline Nursing home, $\mathrm{n}(\%)$ & $0(0.0 \%)$ & $6(0.9 \%)$ & $-0.9 \%(-4.2 \% ; 2.4 \%)$ & \\
\hline Other, n (\%) & $4(12.1 \%)$ & $14(2.2 \%)$ & $10.0 \%(4.4 \% ; 15.5 \%)$ & \\
\hline
\end{tabular}

Depicted are means with standard deviations ( $p$-values from ANOVAs) or counts (\% of all patients; $p$-values from chi-square tests). In $\mathrm{n}: 5$ patients the indication urgent/elective was missing and they were excluded from the analyses. 
Online Table 7. Outcomes urgent vs. elective treatment.

\begin{tabular}{|c|c|c|c|c|c|c|}
\hline & \multicolumn{6}{|c|}{ Clinical outcomes of urgent vs. elective patients } \\
\hline & $\begin{array}{l}\text { Urgent } \\
\mathrm{N}=35\end{array}$ & $\begin{array}{l}\text { Elective } \\
N=657\end{array}$ & $\begin{array}{l}\text { HR or RR } \\
(95 \% \mathrm{CI})\end{array}$ & $p$-value & $\begin{array}{c}\text { Adjusted HR or RR } \\
\text { (95\% Cl) }\end{array}$ & $p$-value \\
\hline \multicolumn{7}{|l|}{ 30-day follow-up - events } \\
\hline Mortality, n (\%) & $4(11.6)$ & $29(4.5)$ & $2.74(0.96-7.81)$ & 0.058 & $2.61(0.91-7.52)$ & 0.075 \\
\hline Cardiovascular mortality, $\mathrm{n}(\%)$ & $4(11.6)$ & $29(4.5)$ & $2.74(0.96-7.81)$ & 0.058 & $2.61(0.91-7.52)$ & 0.075 \\
\hline Cerebrovascular accident, n (\%) & $0(0.0)$ & $22(3.4)$ & $0.41(0.03-6.62)$ & 0.62 & & \\
\hline Major stroke, n (\%) & $0(0.0)$ & $16(2.4)$ & $0.56(0.03-9.15)$ & 1.00 & & \\
\hline Minor stroke, n (\%) & $0(0.0)$ & $4(0.6)$ & $2.06(0.11-37.52)$ & 1.00 & & \\
\hline TIA, n (\%) & $0(0.0)$ & $2(0.3)$ & $3.70(0.18-75.63)$ & 1.00 & & \\
\hline Myocardial infarction, n (\%) & $0(0.0)$ & $3(0.5)$ & $2.65(0.14-50.32)$ & 1.00 & & \\
\hline Acute kidney injury, n (\%) & $4(12.2)$ & $45(7.0)$ & $1.80(0.65-5.01)$ & 0.26 & $1.59(0.57-4.44)$ & 0.38 \\
\hline Stage $1, \mathrm{n}(\%)$ & $4(12.2)$ & $21(3.2)$ & $3.87(1.33-11.29)$ & 0.013 & $3.43(1.16-10.10)$ & 0.026 \\
\hline Stage 2, n (\%) & $0(0.0)$ & $7(1.1)$ & $1.23(0.07-21.11)$ & 1.00 & & \\
\hline Stage 3, n (\%) & $0(0.0)$ & $17(2.6)$ & $0.53(0.03-8.64)$ & 1.00 & & \\
\hline Bleeding, n (\%) & $7(20.5)$ & $103(15.9)$ & $1.37(0.64-2.95)$ & 0.42 & $1.48(0.68-3.19)$ & 0.32 \\
\hline Life-threatening bleeding, n (\%) & $3(8.7)$ & $37(5.7)$ & $1.60(0.49-5.18)$ & 0.44 & $1.60(0.49-5.23)$ & 0.44 \\
\hline Major bleeding, n (\%) & $3(9.0)$ & $55(8.5)$ & $1.07(0.34-3.43)$ & 0.90 & $1.23(0.38-3.95)$ & 0.73 \\
\hline Minor bleeding, n (\%) & $1(3.0)$ & $11(1.7)$ & $1.85(0.24-14.29)$ & 0.56 & $1.76(0.22-13.79)$ & 0.59 \\
\hline $\begin{array}{l}\text { Vascular access-site and access-related } \\
\text { complications, } \mathrm{n}(\%)\end{array}$ & $8(22.9)$ & $73(11.1)$ & 2.09 (1.01-4.33) & 0.048 & $2.09(1.00-4.36)$ & 0.05 \\
\hline Major vascular complications, $\mathrm{n}(\%)$ & $3(8.6)$ & $40(6.1)$ & $1.42(0.44-4.60)$ & 0.56 & $1.38(0.43-4.51)$ & 0.59 \\
\hline Minor vascular complications, $\mathrm{n}(\%)$ & $5(14.3)$ & $34(5.2)$ & $2.76(1.08-7.06)$ & 0.034 & $2.91(1.12-7.53)$ & 0.028 \\
\hline Permanent pacemaker implanted, $n$ (\%) & $4(12.4)$ & $136(21.1)$ & $0.57(0.21-1.53)$ & 0.26 & $0.55(0.20-1.48)$ & 0.24 \\
\hline \multicolumn{7}{|c|}{$\begin{array}{l}\text { Depicted are number of first events with \% of all patients (in-hospital events); and censored at } 30 \text { days since procedure with \% from Kaplan-Meier } \\
\text { estimates (30-day follow-up events). All clinical outcomes were adjudicated, except for pacemaker implantations. Cox's regression, reports hazard ratio } \\
\text { (HR; with 95\% confidence intervals). Continuity corrected RR }(95 \% \mathrm{Cl} \text { ) with } p \text {-value from Fisher's exact test in case of zero events. Adjusted HR or RR: } \\
\text { adjusted for age, gender, previous cardiac surgery, peripheral vascular disease, coronary artery disease. In n: } 5 \text { patients the indication urgent/elective } \\
\text { was missing and they were excluded from the analyses. }\end{array}$} \\
\hline
\end{tabular}


Online Table 8. Baseline one vs. more than one prosthesis.

\begin{tabular}{|c|c|c|c|c|c|}
\hline & \multicolumn{4}{|c|}{$\begin{array}{l}\text { Baseline characteristics comparing patients with one prosthesis vs. } \\
\text { two or more prostheses }\end{array}$} \\
\hline & & $\begin{array}{c}\text { Two or more } \\
\text { prostheses } \\
N=30\end{array}$ & $\begin{array}{c}\text { One prosthesis } \\
\mathrm{N}=667\end{array}$ & $\begin{array}{l}\text { Difference } \\
\text { (95\% Cl) }\end{array}$ & $p$-value \\
\hline \multicolumn{2}{|l|}{ Age (years) } & $81.3 \pm 5.5$ & $82.4 \pm 6.2$ & $-1.1(-3.3 ; 1.2)$ & 0.35 \\
\hline \multicolumn{2}{|c|}{ Female gender, $\mathrm{n}(\%)$} & $14(46.7 \%)$ & $345(51.7 \%)$ & $-5.1 \%(-23.4 \% ; 13.3 \%)$ & 0.71 \\
\hline \multicolumn{2}{|c|}{ Body mass index $\left(\mathrm{kg} / \mathrm{m}^{2}\right)$} & $26.5 \pm 5.2$ & $26.3 \pm 5.0$ & $0.1(-1.7 ; 2.0)$ & 0.88 \\
\hline \multirow{3}{*}{$\begin{array}{l}\text { Cardiac risk } \\
\text { factors }\end{array}$} & Diabetes mellitus, n (\%) & $8(26.7 \%)$ & $196(29.4 \%)$ & $2.7 \%(-14.0 \% ; 19.4 \%)$ & 0.84 \\
\hline & Dyslipidaemia, n (\%) & $19(63.3 \%)$ & $368(55.2 \%)$ & $-8.2 \%(-26.4 \% ; 10.1 \%)$ & 0.45 \\
\hline & Hypertension, n (\%) & $22(73.3 \%)$ & $552(82.8 \%)$ & $9.4 \%(-4.5 \% ; 23.4 \%)$ & 0.22 \\
\hline \multirow{4}{*}{$\begin{array}{l}\text { Past medical } \\
\text { history }\end{array}$} & Previous pacemaker implantation, $\mathrm{n}(\%)$ & $1(3.3 \%)$ & $68(10.2 \%)$ & $6.9 \%(-4.1 \% ; 17.8 \%)$ & 0.35 \\
\hline & Previous myocardial infarction, n (\%) & $3(10.0 \%)$ & $102(15.3 \%)$ & $5.3 \%(-7.8 \% ; 18.4 \%)$ & 0.60 \\
\hline & Previous cardiac surgery, $\mathrm{n}(\%)$ & $4(13.3 \%)$ & $100(15.0 \%)$ & $1.7 \%(-11.4 \% ; 14.7 \%)$ & 1.00 \\
\hline & Previous stroke, n (\%) & $5(16.7 \%)$ & $78(11.7 \%)$ & $-5.0 \%(-16.9 \% ; 6.9 \%)$ & 0.39 \\
\hline \multirow{6}{*}{$\begin{array}{l}\text { Clinical } \\
\text { features }\end{array}$} & Peripheral vascular disease, $\mathrm{n}(\%)$ & $6(20.0 \%)$ & $131(19.6 \%)$ & $-0.4 \%(-14.9 \% ; 14.2 \%)$ & 1.00 \\
\hline & Chronic obstructive pulmonary disease, n (\%) & $4(13.3 \%)$ & 105 (15.7\%) & $2.4 \%(-10.9 \% ; 15.7 \%)$ & 1.00 \\
\hline & Coronary artery disease, $\mathrm{n}(\%)$ & $16(53.3 \%)$ & $374(56.1 \%)$ & $2.7 \%(-15.5 \% ; 21.0 \%)$ & 0.85 \\
\hline & Left ventricular ejection fraction (\%) & $58.9 \pm 12.9$ & $53.6 \pm 14.1$ & $5.4(-0.6 ; 11.3)$ & 0.076 \\
\hline & Aortic valve area $\left(\mathrm{cm}^{2}\right)$ & $0.78 \pm 0.3$ & $0.74 \pm 0.3$ & $0.04(-0.06 ; 0.15)$ & 0.42 \\
\hline & Mean transaortic gradient $(\mathrm{mmHg})$ & $51.8 \pm 19.0$ & $44.5 \pm 17.3$ & $7.3(0.0 ; 14.6)$ & 0.05 \\
\hline \multirow{2}{*}{$\begin{array}{l}\text { Risk } \\
\text { assessment }\end{array}$} & Log. EuroSCORE (\%) & $15.8 \pm 8.7$ & $20.4 \pm 12.8$ & $-4.6(-9.8 ; 0.6)$ & 0.083 \\
\hline & STS score $(\%)$ & $6.4 \pm 4.5$ & $8.3 \pm 7.2$ & $-1.9(-4.5 ; 0.8)$ & 0.16 \\
\hline
\end{tabular}


Online Table 9. Procedure one vs. more than one prosthesis.

\begin{tabular}{|c|c|c|c|c|}
\hline & \multicolumn{4}{|c|}{$\begin{array}{l}\text { Procedural characteristics comparing patients with one prosthesis vs. two } \\
\text { or more prostheses }\end{array}$} \\
\hline & $\begin{array}{c}\text { Two or more } \\
\text { prostheses } N=30\end{array}$ & $\begin{array}{l}\text { One prosthesis } \\
\quad \mathrm{N}=667\end{array}$ & Difference $(95 \%$ CI) & $p$-value \\
\hline Procedure time (min) & $114.1 \pm 65.3$ & $74.1 \pm 35.4$ & $40.0(25.6 ; 54.1)$ & $<0.001$ \\
\hline Amount of contrast (ml) & $309.5 \pm 107.1$ & $210.7 \pm 105.5$ & $98.8(59.4 ; 138.2)$ & $<0.001$ \\
\hline General anaesthesia, n (\%) & $7(23.3 \%)$ & $373(56.0 \%)$ & $-32.7 \%(-50.8 \% ;-14.6 \%)$ & 0.001 \\
\hline Conversion from local to general anaesthesia, n (\%) & $2(8.7 \%)$ & $14(4.8 \%)$ & $-3.9 \%(-13.3 \% ; 5.4 \%)$ & 0.33 \\
\hline Procedure location & & & & 0.70 \\
\hline Catheterisation laboratory, n (\%) & $24(80.0 \%)$ & $496(74.4 \%)$ & $5.6 \%(-10.3 \% ; 21.6 \%)$ & \\
\hline Operating room, n (\%) & $0(0.0 \%)$ & $8(1.2 \%)$ & $-1.2 \%(-5.1 \% ; 2.7 \%)$ & \\
\hline Hybrid room, n (\%) & $6(20.0 \%)$ & $163(24.4 \%)$ & $-4.4 \%(-20.2 \% ; 11.3 \%)$ & \\
\hline Access-site location & & & & 0.12 \\
\hline Femoral & $29(96.7 \%)$ & $522(78.3 \%)$ & $18.4 \%(3.5 \% ; 33.3 \%)$ & \\
\hline Transapical & $1(3.3 \%)$ & $125(18.7 \%)$ & $-15.4 \%(-29.5 \% ;-1.3 \%)$ & \\
\hline Subclavian & $0(0.0 \%)$ & $8(1.2 \%)$ & $-1.2 \%(-5.1 \% ; 2.7 \%)$ & \\
\hline Direct aortic & $0(0.0 \%)$ & $12(1.8 \%)$ & $-1.8 \%(-6.6 \% ; 3.0 \%)$ & \\
\hline \multicolumn{5}{|l|}{ Concomitant procedure } \\
\hline Percutaneous coronary intervention, n (\%) & $1(3.3 \%)$ & $64(9.6 \%)$ & $6.3 \%(-4.4 \% ; 16.9 \%)$ & 0.35 \\
\hline \multicolumn{5}{|l|}{ Device features } \\
\hline Prior balloon aortic valvuloplasty, n (\%) & $25(83.3 \%)$ & $579(86.8 \%)$ & $3.5 \%(-9.0 \% ; 15.9 \%)$ & 0.58 \\
\hline Device implanted & & & & $<0.001$ \\
\hline Medtronic CoreValve, n (\%) & $28(93.3 \%)$ & $308(46.4 \%)$ & $46.9 \%(28.9 \% ; 65.0 \%)$ & \\
\hline Edwards SAPIEN XT, n (\%) & $2(6.7 \%)$ & $315(47.4 \%)$ & $-40.8 \%(-58.8 \% ;-22.7 \%)$ & \\
\hline Symetis Acurate, n (\%) & $0(0.0 \%)$ & $17(2.6 \%)$ & $-2.6 \%(-8.2 \% ; 3.1 \%)$ & \\
\hline JenaValve, n (\%) & $0(0.0 \%)$ & $23(3.5 \%)$ & $-3.5 \%(-10.0 \% ; 3.1 \%)$ & \\
\hline SJM Portico, n (\%) & $0(0.0 \%)$ & $1(0.2 \%)$ & $-0.2 \%(-1.5 \% ; 1.2 \%)$ & \\
\hline Aortic regurgitation post TAVI & & & & 0.23 \\
\hline Grade $0, \mathrm{n}(\%)$ & $6(20.0 \%)$ & $164(25.2 \%)$ & $-5.2 \%(-21.0 \% ; 10.7 \%)$ & \\
\hline Grade $1, \mathrm{n}(\%)$ & $19(63.3 \%)$ & $433(66.4 \%)$ & $-3.1 \%(-20.4 \% ; 14.3 \%)$ & \\
\hline Grade $2, \mathrm{n}(\%)$ & $4(13.3 \%)$ & $51(7.8 \%)$ & $5.5 \%(-4.5 \% ; 15.5 \%)$ & \\
\hline Grade 3, n (\%) & $1(3.3 \%)$ & $4(0.6 \%)$ & $2.7 \%(-0.4 \% ; 5.8 \%)$ & \\
\hline \multicolumn{5}{|l|}{ In-hospital course } \\
\hline Permanent pacemaker implantation, n (\%) & $9(30.0 \%)$ & $128(19.5 \%)$ & $-10.5 \%(-25.2 \% ; 4.1 \%)$ & 0.16 \\
\hline Any packed red blood cell during hospitalisation, n (\%) & $8(26.7 \%)$ & $123(18.6 \%)$ & $-8.1 \%(-22.5 \% ; 6.2 \%)$ & 0.34 \\
\hline Number of PRBC, median (interquartile range) & $2.0(1.0 ; 3.5)$ & $2.0(1.0 ; 3.0)$ & $3.9(1.3 ; 6.6)$ & 0.82 \\
\hline Overall in-hospital stay after TAVI (days) & $13.6 \pm 9.7$ & $10.6 \pm 5.9$ & $3.0(0.8 ; 5.3)$ & 0.01 \\
\hline Stay at intensive care unit (days) & $3.0 \pm 7.9$ & $1.0 \pm 1.7$ & $2.0(1.1 ; 2.8)$ & $<0.001$ \\
\hline Stay at intermediate care (days) & $2.6 \pm 2.8$ & $2.5 \pm 2.9$ & $0.1(-1.0 ; 1.2)$ & 0.85 \\
\hline Stay at general ward (days) & $8.0 \pm 8.6$ & $7.1 \pm 5.1$ & $0.9(-1.0 ; 2.9)$ & 0.35 \\
\hline Patient discharged to & & & & 0.64 \\
\hline Home, n (\%) & $8(26.7 \%)$ & $189(29.0 \%)$ & $-2.4 \%(-19.0 \% ; 14.3 \%)$ & \\
\hline Referring hospital, n (\%) & $6(20.0 \%)$ & $158(24.3 \%)$ & $-4.3 \%(-20.0 \% ; 11.4 \%)$ & \\
\hline Rehabilitation clinic, n (\%) & $14(46.7 \%)$ & $282(43.3 \%)$ & $3.3 \%(-14.9 \% ; 21.5 \%)$ & \\
\hline Nursing home, n (\%) & $0(0.0 \%)$ & $6(0.9 \%)$ & $-0.9 \%(-4.4 \% ; 2.5 \%)$ & \\
\hline Other, n (\%) & $2(6.7 \%)$ & $16(2.5 \%)$ & $4.2 \%(-1.7 \% ; 10.1 \%)$ & \\
\hline
\end{tabular}

Depicted are means with standard deviations ( $p$-values from ANOVAs) or counts (\% of all patients; $p$-values from chi-square tests). 
Online Table 10. Outcomes one vs. more than one prosthesis.

\begin{tabular}{|c|c|c|c|c|c|c|}
\hline & \multicolumn{6}{|c|}{ Clinical outcomes comparing patients with one prosthesis vs. two or more prostheses } \\
\hline & $\begin{array}{l}\text { Two or more } \\
\text { prostheses } \\
\quad N=30\end{array}$ & $\begin{array}{l}\text { One } \\
\text { prosthesis } \\
\mathrm{N}=667\end{array}$ & $\begin{array}{l}\text { HR or RR } \\
\text { (95\% CI) }\end{array}$ & $p$-value & $\begin{array}{c}\text { Adjusted HR } \\
\text { or RR (95\% CI) }\end{array}$ & $p$-value \\
\hline \multicolumn{7}{|l|}{ 30-day follow-up - events } \\
\hline Mortality, n (\%) & $2(6.7)$ & $31(4.7)$ & $1.48(0.35-6.18)$ & 0.59 & $1.71(0.41-7.17)$ & 0.46 \\
\hline Cardiovascular mortality, n (\%) & $2(6.7)$ & $31(4.7)$ & $1.48(0.35-6.18)$ & 0.59 & $1.71(0.41-7.17)$ & 0.46 \\
\hline Cerebrovascular accident, n (\%) & $0(0.0)$ & $23(3.5)$ & $0.47(0.03-7.56)$ & 0.62 & & \\
\hline Major stroke, n (\%) & $0(0.0)$ & $17(2.6)$ & $0.63(0.04-10.23)$ & 1.00 & & \\
\hline Minor stroke, n (\%) & $0(0.0)$ & $4(0.6)$ & $2.43(0.13-44.12)$ & 1.00 & & \\
\hline TIA, n (\%) & $0(0.0)$ & $2(0.3)$ & $4.38(0.21-89.27)$ & 1.00 & & \\
\hline Myocardial infarction, n (\%) & $0(0.0)$ & $3(0.5)$ & $3.13(0.17-59.26)$ & 1.00 & & \\
\hline Acute kidney injury, n (\%) & $2(6.9)$ & $48(7.3)$ & $0.95(0.23-3.91)$ & 0.94 & $0.96(0.23-3.94)$ & 0.95 \\
\hline Stage $1, \mathrm{n}(\%)$ & $2(6.9)$ & $24(3.7)$ & $1.92(0.45-8.12)$ & 0.38 & $1.89(0.45-8.02)$ & 0.39 \\
\hline Stage $2, \mathrm{n}(\%)$ & $0(0.0)$ & $7(1.1)$ & $1.46(0.09-24.98)$ & 1.00 & & \\
\hline Stage 3, n (\%) & $0(0.0)$ & $17(2.6)$ & $0.63(0.04-10.23)$ & 1.00 & & \\
\hline Bleeding, n (\%) & $9(30.2)$ & 105 (15.9) & $2.07(1.05-4.09)$ & 0.036 & $2.08(1.05-4.13)$ & 0.035 \\
\hline Life-threatening bleeding, $\mathrm{n}(\%)$ & $3(10.0)$ & $40(6.1)$ & $1.72(0.53-5.57)$ & 0.36 & $1.75(0.54-5.67)$ & 0.35 \\
\hline Major bleeding, $\mathrm{n}(\%)$ & $4(13.9)$ & $54(8.2)$ & $1.70(0.62-4.71)$ & 0.30 & $1.66(0.60-4.63)$ & 0.33 \\
\hline Minor bleeding, n (\%) & $2(6.9)$ & $11(1.7)$ & $4.27(0.95-19.28)$ & 0.059 & $4.81(1.05-21.93)$ & 0.042 \\
\hline $\begin{array}{l}\text { Vascular access-site and access-related } \\
\text { complications, } \mathrm{n}(\%)\end{array}$ & $6(20.1)$ & $77(11.6)$ & $1.74(0.76-4.00)$ & 0.19 & $1.78(0.77-4.09)$ & 0.18 \\
\hline Major vascular complications, n (\%) & $4(13.5)$ & $41(6.2)$ & $2.19(0.78-6.10)$ & 0.14 & $2.24(0.80-6.29)$ & 0.13 \\
\hline Minor vascular complications, n (\%) & $2(6.7)$ & $37(5.5)$ & $1.20(0.29-4.99)$ & 0.80 & $1.22(0.29-5.09)$ & 0.78 \\
\hline Permanent pacemaker implanted, n (\%) & $9(31.6)$ & $131(20.0)$ & $1.65(0.84-3.24)$ & 0.15 & $1.64(0.84-3.23)$ & 0.15 \\
\hline \multicolumn{7}{|c|}{$\begin{array}{l}\text { Depicted are number of first events with \% of all patients (in-hospital events); and censored at } 30 \text { days since procedure with \% from Kaplan-Meier } \\
\text { estimates ( } 30 \text {-day follow-up events). All clinical outcomes were adjudicated, except for pacemaker implantations. Cox's regression, reports hazard ratio } \\
\text { (HR; with 95\% confidence intervals). Continuity corrected RR }(95 \% \mathrm{Cl} \text { ) with } p \text {-value from Fisher's exact test in case of zero events. }\end{array}$} \\
\hline
\end{tabular}

\section{Online Table 11. Baseline discharge home vs. others.}

\begin{tabular}{|c|c|c|c|c|c|}
\hline & \multicolumn{4}{|c|}{ Baseline characteristics for patients discharged home vs. others } \\
\hline & & Home $N=197$ & Others $N=500$ & Difference $(95 \%$ CI) & p-value \\
\hline \multicolumn{2}{|l|}{ Age (years) } & $81.6 \pm 7.1$ & $82.7 \pm 5.7$ & $-1.1(-2.1 ;-0.1)$ & 0.036 \\
\hline \multicolumn{2}{|c|}{ Female gender, n (\%) } & $78(39.6 \%)$ & $281(56.2 \%)$ & $-16.6 \%(-24.8 \% ;-8.4 \%)$ & $<0.001$ \\
\hline \multicolumn{2}{|c|}{ Body mass index $\left(\mathrm{kg} / \mathrm{m}^{2}\right)$} & $26.6 \pm 5.2$ & $26.2 \pm 4.9$ & $0.5(-0.4 ; 1.3)$ & 0.28 \\
\hline \multirow{3}{*}{$\begin{array}{l}\text { Cardiac risk } \\
\text { factors }\end{array}$} & Diabetes mellitus, n (\%) & $52(26.4 \%)$ & $152(30.4 \%)$ & $4.0 \%(-3.5 \% ; 11.5 \%)$ & 0.31 \\
\hline & Dyslipidaemia, n (\%) & $107(54.3 \%)$ & $280(56.0 \%)$ & $1.7 \%(-6.5 \% ; 9.9 \%)$ & 0.74 \\
\hline & Hypertension, n (\%) & $163(82.7 \%)$ & $411(82.2 \%)$ & $-0.5 \%(-6.8 \% ; 5.8 \%)$ & 0.91 \\
\hline \multirow{4}{*}{$\begin{array}{l}\text { Past medical } \\
\text { history }\end{array}$} & Previous pacemaker implantation, $\mathrm{n}(\%)$ & $24(12.2 \%)$ & $45(9.0 \%)$ & $-3.2 \%(-8.1 \% ; 1.8 \%)$ & 0.21 \\
\hline & Previous myocardial infarction, n (\%) & $29(14.7 \%)$ & $76(15.2 \%)$ & $0.5 \%(-5.4 \% ; 6.4 \%)$ & 0.91 \\
\hline & Previous cardiac surgery, $\mathrm{n}(\%)$ & $36(18.3 \%)$ & $68(13.6 \%)$ & $-4.7 \%(-10.6 \% ; 1.2 \%)$ & 0.13 \\
\hline & Previous stroke, n (\%) & $15(7.6 \%)$ & $68(13.6 \%)$ & $6.0 \%(0.6 \% ; 11.3 \%)$ & 0.028 \\
\hline \multirow[t]{6}{*}{ Clinical features } & Peripheral vascular disease, $\mathrm{n}(\%)$ & $37(18.8 \%)$ & $100(20.0 \%)$ & $1.2 \%(-5.4 \% ; 7.8 \%)$ & 0.75 \\
\hline & Chronic obstructive pulmonary disease, $\mathrm{n}(\%)$ & $34(17.3 \%)$ & $75(15.0 \%)$ & $-2.3 \%(-8.3 \% ; 3.7 \%)$ & 0.49 \\
\hline & Coronary artery disease, $\mathrm{n}(\%)$ & $111(56.3 \%)$ & $279(55.8 \%)$ & $-0.5 \%(-8.8 \% ; 7.7 \%)$ & 0.93 \\
\hline & Left ventricular ejection fraction (\%) & $55.9 \pm 12.4$ & $52.9 \pm 14.7$ & $3.0(0.2 ; 5.8)$ & 0.034 \\
\hline & Aortic valve area $\left(\mathrm{cm}^{2}\right)$ & $0.8 \pm 0.3$ & $0.7 \pm 0.2$ & $0.1(0.04 ; 0.1)$ & 0.001 \\
\hline & Mean transaortic gradient $(\mathrm{mmHg})$ & $43.0 \pm 14.5$ & $45.6 \pm 18.5$ & $-2.6(-6.0 ; 0.9)$ & 0.14 \\
\hline \multirow[t]{2}{*}{ Risk assessment } & Log. EuroSCORE (\%) & $19.3 \pm 12.8$ & $20.5 \pm 12.6$ & $-1.2(-3.8 ; 1.4)$ & 0.36 \\
\hline & STS score (\%) & $7.7 \pm 7.2$ & $8.4 \pm 7.1$ & $-0.8(-2.0 ; 0.4)$ & 0.20 \\
\hline
\end{tabular}

Depicted are means with standard deviations ( $p$-values from ANOVAs) or counts (\% of all patients; $p$-values from chi-square tests). In $\mathrm{n}: 16$ patients the discharge location was unclear and assumed others. 
Online Table 12. Procedure discharge home vs. others.

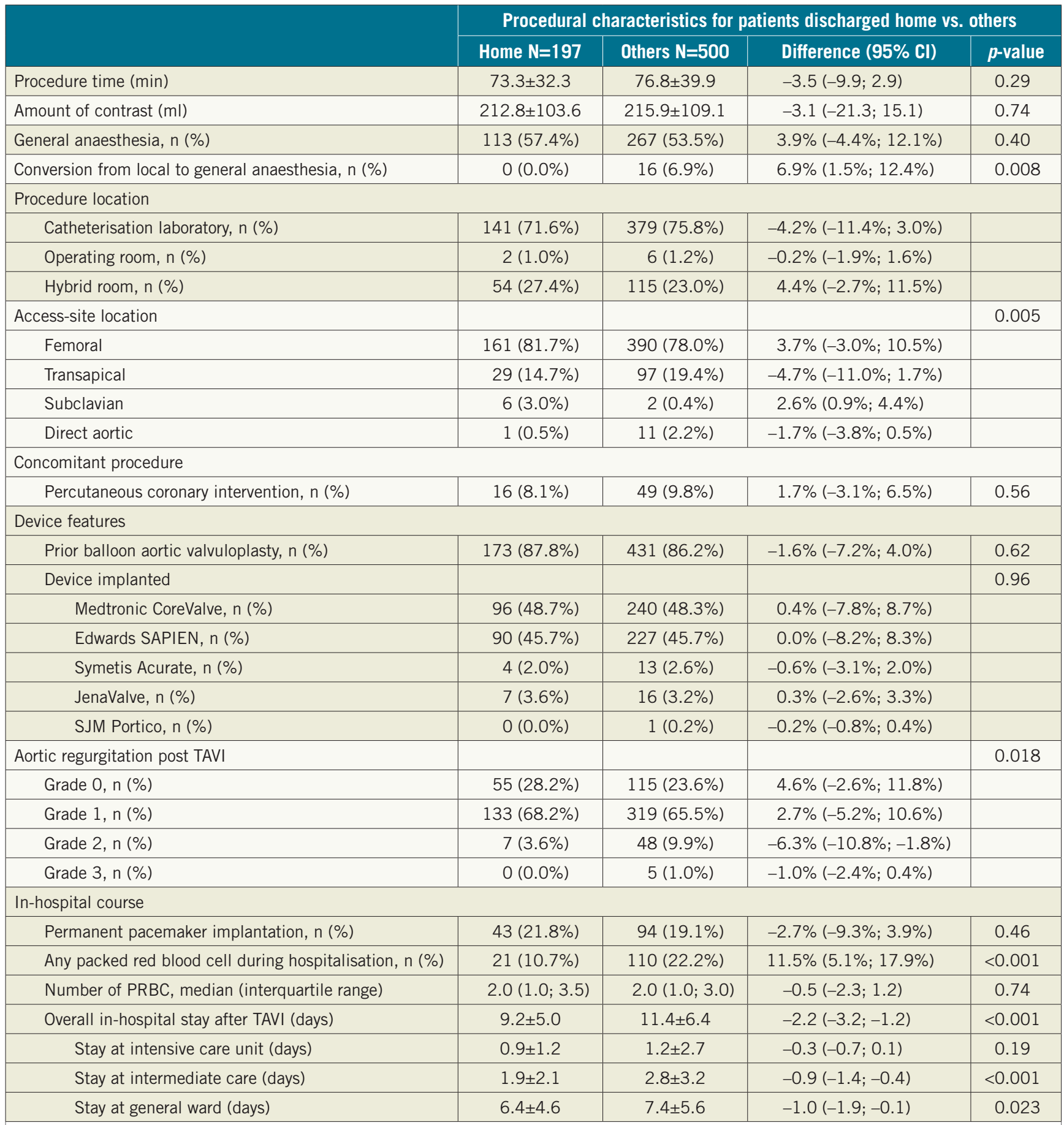

Depicted are means with standard deviations ( $p$-values from ANOVAs) or counts ( $\%$ of all patients; $p$-values from chi-square tests). In $\mathrm{n}: 16$ patients the discharge location was unclear and assumed others. 
Online Table 13. Outcomes discharge home vs. others.

\begin{tabular}{|c|c|c|c|c|c|c|}
\hline & \multicolumn{6}{|c|}{ Clinical outcomes comparing patients discharged home vs. others } \\
\hline & $\begin{array}{c}\text { Home } \\
\mathrm{N}=197\end{array}$ & $\begin{array}{l}\text { Others } \\
N=500\end{array}$ & HR or RR $(95 \% \mathrm{CI})$ & $p$-value & $\begin{array}{c}\text { Adjusted HR or RR } \\
(95 \% \text { Cl) }\end{array}$ & $p$-value \\
\hline \multicolumn{7}{|l|}{ 30-day follow-up - events } \\
\hline Mortality, n (\%) & $0(0.0)$ & $33(6.7)$ & $0.04(0.00-0.65)$ & $<0.001$ & & \\
\hline Cardiovascular mortality, $\mathrm{n}(\%)$ & $0(0.0)$ & $33(6.7)$ & $0.04(0.00-0.65)$ & $<0.001$ & & \\
\hline Cerebrovascular accident, $\mathrm{n}(\%)$ & $1(0.5)$ & $22(4.5)$ & $0.11(0.02-0.84)$ & 0.033 & $0.12(0.02-0.92)$ & 0.041 \\
\hline Major stroke, n (\%) & $1(0.5)$ & $16(3.2)$ & $0.16(0.02-1.18)$ & 0.072 & $0.17(0.02-1.30)$ & 0.088 \\
\hline Minor stroke, $\mathrm{n}(\%)$ & $0(0.0)$ & $4(0.8)$ & $0.28(0.02-5.18)$ & 0.58 & & \\
\hline TIA, n (\%) & $0(0.0)$ & $2(0.4)$ & $0.51(0.02-10.58)$ & 1.00 & & \\
\hline Myocardial infarction, n (\%) & $1(0.5)$ & $2(0.4)$ & $1.24(0.11-13.66)$ & 0.86 & $1.15(0.10-13.14)$ & 0.91 \\
\hline Acute kidney injury, n (\%) & $12(6.1)$ & $38(7.8)$ & $0.78(0.41-1.50)$ & 0.46 & $0.76(0.39-1.46)$ & 0.41 \\
\hline Stage $1, \mathrm{n}(\%)$ & $9(4.6)$ & $17(3.5)$ & $1.33(0.59-2.98)$ & 0.49 & $1.22(0.54-2.76)$ & 0.64 \\
\hline Stage 2, n (\%) & $1(0.5)$ & $6(1.2)$ & $0.41(0.05-3.41)$ & 0.41 & $0.52(0.06-4.43)$ & 0.55 \\
\hline Stage 3, n (\%) & $2(1.0)$ & $15(3.1)$ & $0.33(0.08-1.44)$ & 0.14 & $0.31(0.07-1.38)$ & 0.12 \\
\hline Bleeding, n (\%) & $19(9.7)$ & 95 (19.3) & $0.48(0.29-0.79)$ & 0.003 & $0.49(0.30-0.81)$ & 0.005 \\
\hline Life-threatening bleeding, n (\%) & $4(2.0)$ & $39(7.9)$ & $0.25(0.09-0.70)$ & 0.008 & $0.25(0.09-0.71)$ & 0.009 \\
\hline Major bleeding, n (\%) & $11(5.6)$ & $47(9.6)$ & $0.58(0.30-1.11)$ & 0.10 & $0.61(0.32-1.19)$ & 0.15 \\
\hline Minor bleeding, n (\%) & $4(2.0)$ & $9(1.8)$ & $1.10(0.34-3.56)$ & 0.88 & $1.06(0.32-3.52)$ & 0.92 \\
\hline $\begin{array}{l}\text { Vascular access-site and access-related } \\
\text { complications, } \mathrm{n}(\%)\end{array}$ & $12(6.1)$ & $71(14.2)$ & $0.43(0.23-0.78)$ & 0.006 & $0.46(0.25-0.84)$ & 0.013 \\
\hline Major vascular complications, n (\%) & $5(2.5)$ & $40(8.0)$ & $0.31(0.12-0.79)$ & 0.015 & $0.35(0.14-0.90)$ & 0.029 \\
\hline Minor vascular complications, n (\%) & $7(3.6)$ & $32(6.4)$ & $0.56(0.25-1.26)$ & 0.16 & $0.57(0.25-1.30)$ & 0.18 \\
\hline Permanent pacemaker implanted, n (\%) & $43(21.9)$ & 97 (19.9) & $1.11(0.78-1.59)$ & 0.56 & $1.02(0.71-1.47)$ & 0.90 \\
\hline \multicolumn{7}{|c|}{$\begin{array}{l}\text { Depicted are number of first events with \% of all patients (in-hospital events); and censored at } 30 \text { days since procedure with \% from Kaplan-Meier } \\
\text { estimates (30-day follow-up events). All clinical outcomes were adjudicated, except for pacemaker implantations. Cox's regression, reports hazard ratio } \\
\text { (HR; with 95\% confidence intervals). Continuity corrected RR ( } 95 \% \mathrm{Cl} \text { ) with p-value from Fisher's exact test in case of zero events. In } \mathrm{n}: 16 \text { patients } \\
\text { the discharge location was unclear and assumed others. }\end{array}$} \\
\hline
\end{tabular}

